
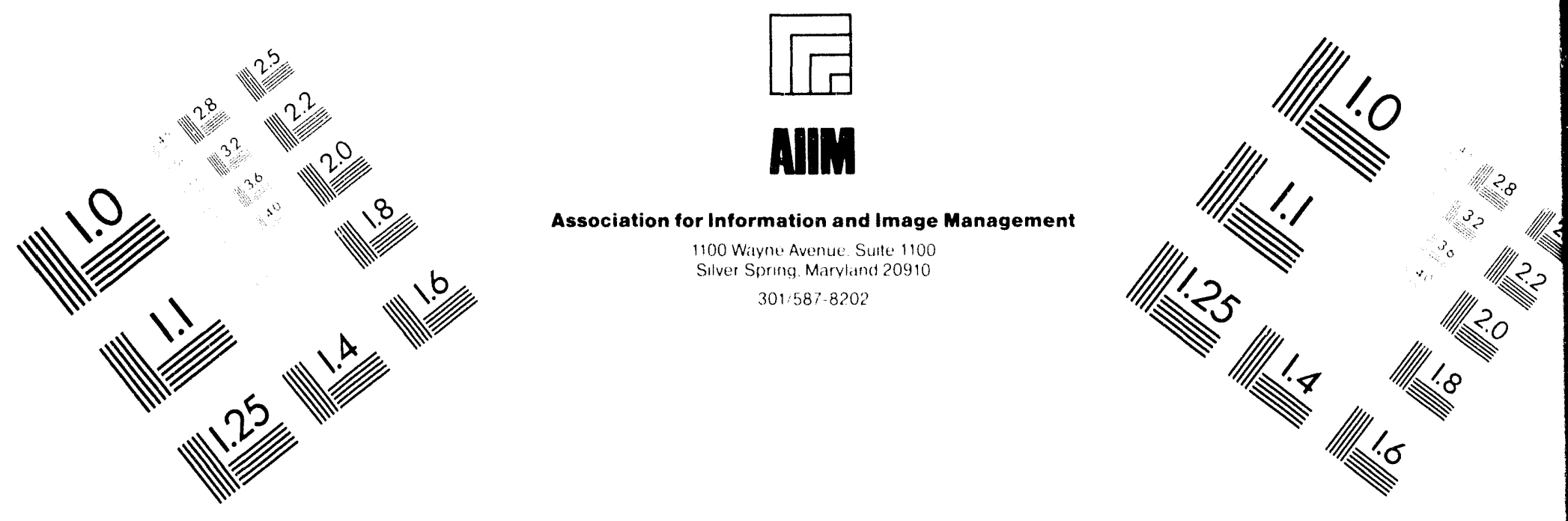

\title{
Centimeter
}

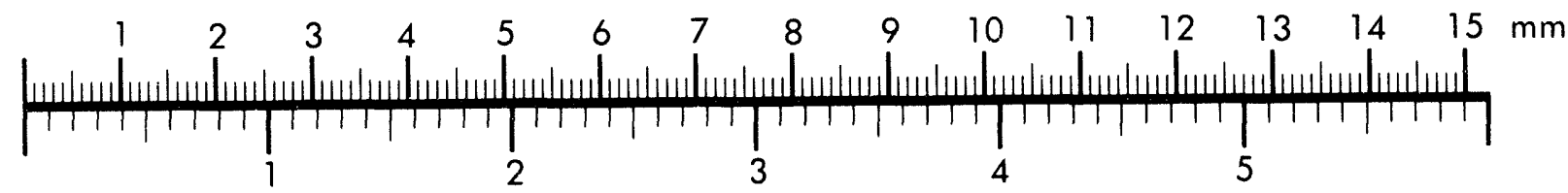

Inches
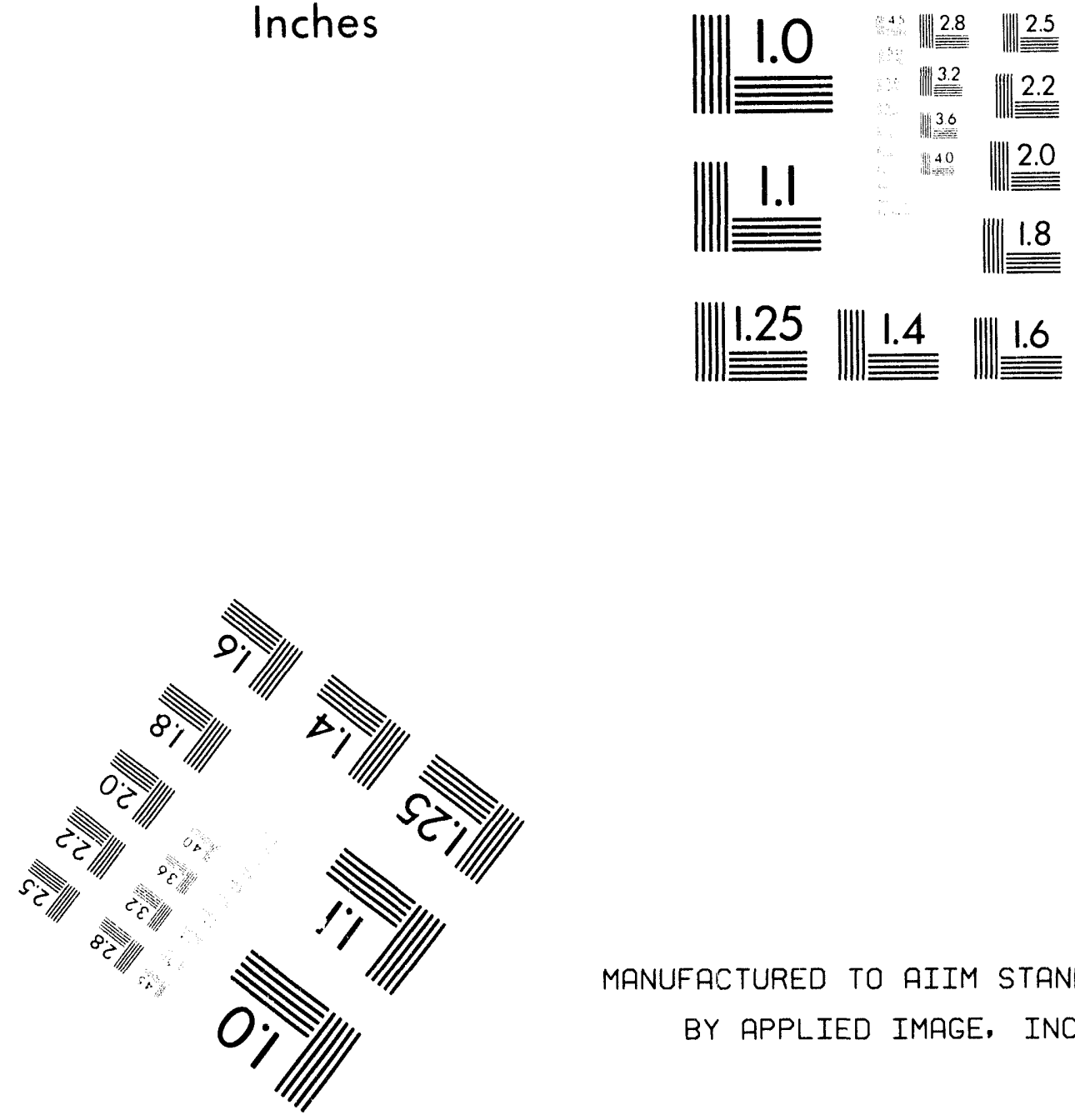

MANUFACTURED TO AIIM STANDARDS

BY APPLIED IMAGE, INC.

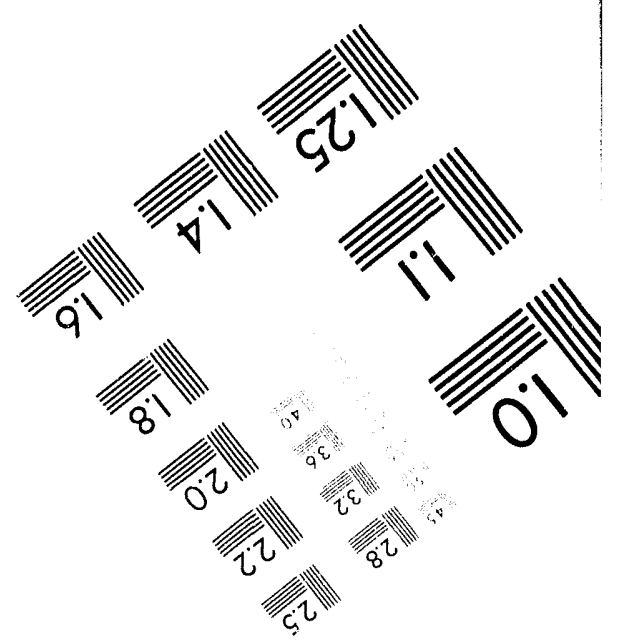



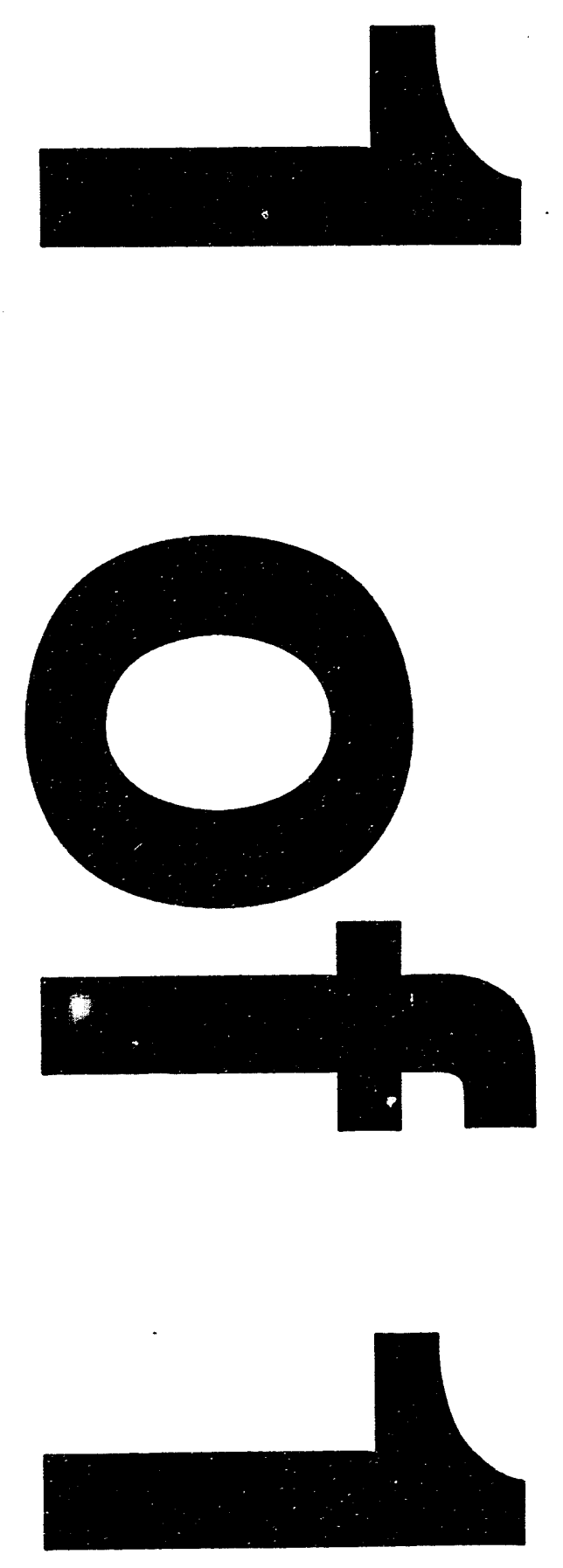


\section{MAXINE: AN IMPROVED METHODOLOGY FOR ESTIMATING MAXIMUM INDIVIDUAL DOSE FROM CHRONIC ATMOSPHERIC RADIOACTIVE RELEASES}

by

D. M. Hamby

Westinghouse Savannah River Company

Savannah River Site

Aiken, South Carolina 29808

This paper was prepared in connection with work done under the above contract number with the U. S. Department of Energy. By acceptance of this paper, the publisher and/or recipient acknowledges the U. S. Government's right to retain a nonexclusive, royalty-free license in and to any copyright covering this paper, along with the right to reproduce and to authorize others to reproduce all or part of the copyrighted paper. 


\section{DISCLAIMER}

This report was prepared as an account of work sponsored by an agency of the United States Government. Neither the United States Government nor any agency thereof, nor any of their employees, makes any warranty, express or implied, or assumes any legal liability or responsibility for the accuracy, completeness, or usefulness of any information, apparatus, product, or process disclosed, or represents that its use would not in ringe privately owned rights. Reference herein to any specific commercial product, process, or service by trade name, trademark. manufacturer, or otherwise does not necessarily constitute or imply its endorsement, recommendation, or favoring by the United States Government or any agency thereof. The views and opinions of authors expressed herein do not necessarily state or reflect those of the United States Government or any agency thereof.

This report has been reproduced directly from the best available copy.

Available to DOE and DOE contractors from the Office of Scientific and Technical Information, P. O. Box 62, Oak Ridge, TN 37831; prices available from (615) $576-8401$.

Available to the public from the National Technical Information Service, U. S. Department of Commerce, 5285 Port Royal Rd., Springfield. VA 22161 
WSRC-TR-94-053

MAXINE: AN IMPROVED METHODOLOGY FOR ESTIMATING MAXIMUM INDIVIDUAL DOSE FROM CHRONIC ATMOSPHERIC RADIOACTIVE

RELEASES

D.M. Hamby

February 1, 1994
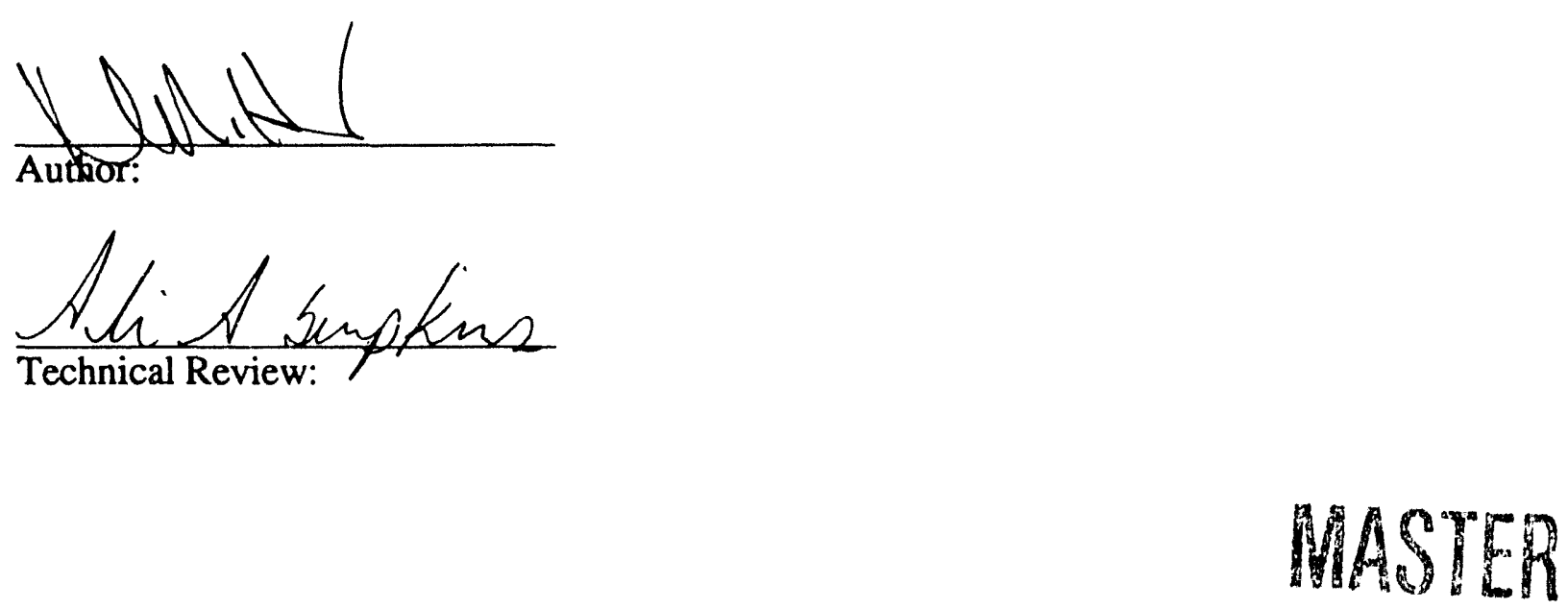

DISTRIBUTION OF THIS DOCUMENT IS UNLIMITEO

Westinghouse Savannah River Company Savannah River Technology Center<smiles>[V]=[Tl]</smiles>
Aiken, SC 29808 


\section{CONTENTS}

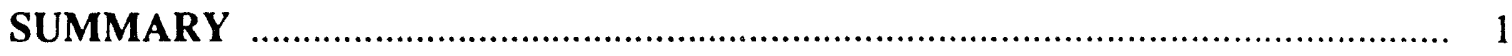

INTRODUCTION ..................................................................................... 1

DETERMINATION OF NUCLIDE CONCENTRATIONS F............................ 2

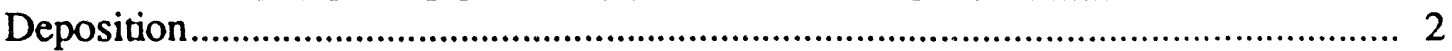

Nuclide Concentrations in the Atmosphere............................................................ 3

Nuclide Concentrations in Vegetation.................................................................... 4

Nuclide Concentrations in Meat and Milk ......................................................... 6

DOSIMETRY MODELS FOR ATMOSPHERIC RELEASES ………………... 7

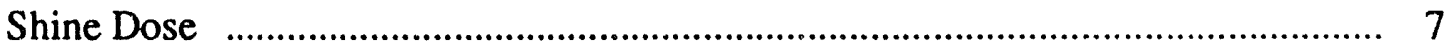

Inhalation Dose

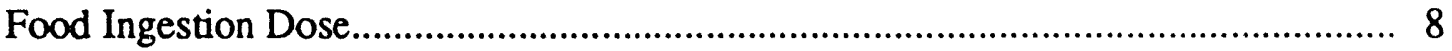

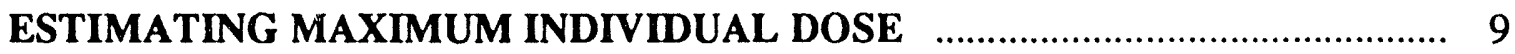

Input Required from XOQDOQ/PC .......................................................... 9

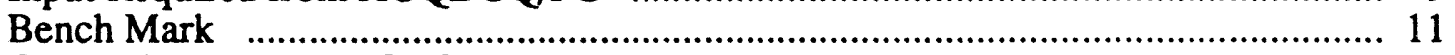

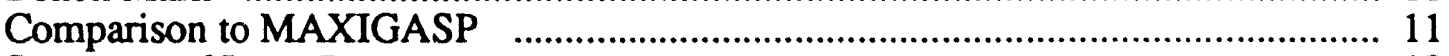

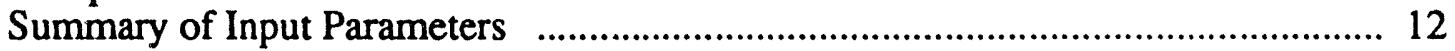

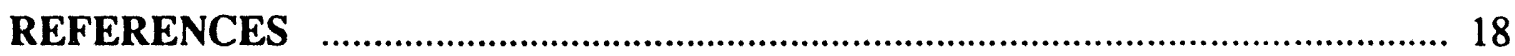




\title{
MAXINE: AN IMPROVED METHODOLOGY FOR ESTIMATING MAXIMUM INDIVIDUAL DOSE FROM CHRONIC ATMOSPHERIC RADIOACTIVE RELEASES
}

\author{
D.M. Hamby \\ Westinghouse Savannah River Company \\ Savannah River Site \\ Aiken, SC 29808
}

\section{SUMMARY}

An EXCEL 8 spreadsheet has been developed that, when combined with the PC version of XOQDOQ, will generate estimates of maximum individual dose from routine atmospheric releases of radionuclides. The spreadsheet, MAXINE, utilizes a variety of atmospheric dispersion factors to calculate radiation dose as recommended by the US Nuclear Regulatory Commission in Regulatory Guide 1.109 [USNRC 1977a]. The methodology suggested herein includes use of both the MAXINE spreadsheet and the PC version of XOQDOQ [USNRC 1977b; Sagendorf et. al. 1982].

\section{INTRODUCTION}

The GASPAR code [Eckerman et. al. 1980] was written in 1977 by Oak Ridge National Laboratory for the Nuclear Regulatory Commission (NRC). The models in GASPAR calculate atmospheric concentrations, deposition rates, concentrations in foodstuffs, and radiation dose to individuals and populations resulting from chronic releases of radionuclides to the atmosphere [USNRC 1977a]. The atmospheric transport models that feed GASPAR are contained in XOQDOQ [USNRC 1977b; Sagendorf et. al. 1982]. About 10 years ago, XOQDOQ and GASPAR were combined calculate maximum individual dose to a receptor at the site boundary from routine atmospheric releases. This combination of codes is referred to as MAXIGASP and resides on the Savannah River Technology Center's (SRTC) unclassified mainframe. 
A new methodology has been developed to take the place of MAXIGASP. Again, it involves the use of two primary models: (1) an environmental transport model (XOQDOQ/PC) and (2) a dosimetry model (MAXINE). The PC version of XOQDOQ contains the dispersion model identical to that of the mainframe version and is utilized to calculate downwind relative air concentrations accounting for decay and deposition. XOQDOQ/PC [Sagendorf et. al. 1982] also calculates a relative deposition rate for the release scenario. The relative concentrations are then used as input for the MAXINE spreadsheet. This spreadsheet is written in EXCEL $\otimes$ and contains concentration and dosimetry models similar to GASPAR.

The new PC-based methodology is an improvement over the previous mainframe method. Quality assurance is enhanced because changes to the spreadsheet are password protected and all input values are included as part of the output. Additionally, use of the cumbersome mainframe is eliminated and modeling versatility is improved.

\section{DETERMINATION OF NUCLIDE CONCENTRATIONS}

\section{Deposition}

Deposition of iodines and particulates occurs by several mechanisms. The primary removal mechanism of atmospheric material is gravitational settling or contact with the ground, vegetation, or other ground cover such as buildings (dry deposition). Wet deposition also can occur, whereby gases and particulates are removed from an atmospheric plume by precipitive scavenging (rain, sleet, snow). For long-term averages, such as those calculated in MAXINE, dose calculations considering only dry deposition are not changed significantly by the consideration of wet deposition [USNRC 1977b].

Tritium and Carbon-14. Dry deposition of these nuclides is not considered. Specific activity models for tritium and C-14 utilize atmospheric concentrations to estimate vegetation concentrations.

Other Nuclides. Deposition rates, $\mathrm{d}_{\mathrm{i}}$, for all remaining nuclides are estimated using,

$$
\mathrm{d}_{\mathrm{i}}\left[\frac{\mu \mathrm{Ci}}{\mathrm{m}^{2} \mathrm{yr}}\right]=\frac{\mathrm{D}}{\mathrm{Q}}\left[\frac{1}{\mathrm{~m}^{2}}\right] \cdot \mathrm{Q}_{\mathrm{i}}\left[\frac{\mu \mathrm{Ci}}{\mathrm{yr}}\right] \cdot \mathrm{e}^{\left(31.62-\lambda_{i}\right) \mathrm{t}_{\mathrm{r}}}
$$


where $\mathrm{D} / \mathrm{Q}$ is the relative deposition value calculated in XOQDOQ/PC, $\mathrm{Q}_{\mathrm{i}}$ is the radionuclide release rate, $\lambda_{i}$ is the nuclide-specific decay constant and $t_{T}$ is the plume travel time from the source to the receptor. The deposition rate is influenced by both radioactive decay and by resuspension of nuclides already deposited. XOQDOQ/PC calculates $\mathrm{D} / \mathrm{Q}$ and depleted $\chi / \mathrm{Q}$ assuming a radiological decay with an 8 day half-life. In order to calculate nuclide-specific decay, the exponential factor 31.62 in Equation 1 compensates for the originally assumed half-life. The nuclide-specific half-lives, $\lambda_{i}$, accounts for decay of the source term nuclides.

The parameter $t_{\mathrm{T}}$ is the average amount of time required for the effluent to reach the receptor (site boundary for maximum individual dose calculations). This value is estimated by dividing the receptor distance by $4.05 \mathrm{~m} / \mathrm{sec}$, the average wind speed at the SRS over the 5-year period 1987-1991 [Weber 1993]. Deposition is modeled for all radionuclides except tritium, carbon-14, and the noble gases.

Deposition rate equations for the iodine isotopes include a factor to account for the fraction of the release that is in elemental form; only the elemental form of iodine is assumed to deposit on ground surfaces. For iodine isotopes, Equation 1 is multiplied by, $\mathrm{F}_{\mathrm{I}}$, the fraction of iodine that is assumed to be elemental. The non-elemental fraction of iodine is assumed not to deposit on the ground.

\section{Nuclide Concentrations in the Atmosphere}

Tritium, Carbon-14, and Noble Gases. Downwind atmospheric concentrations of tritium, $\mathrm{C}-14$, and noble gases are estimated using,

$$
\chi_{i}\left[\frac{\mu \mathrm{Ci}}{\mathrm{m}^{3}}\right]=\frac{\chi}{\mathrm{Q}}\left[\frac{\mathrm{sec}}{\mathrm{m}^{3}}\right] \cdot \mathrm{Q}_{\mathrm{i}}\left[\frac{\mu \mathrm{Ci}}{\mathrm{sec}}\right] \cdot \mathrm{e}^{\lambda_{i} \tau_{T}}
$$

where the exponential accounts for radioactive decay during transit to the maximum individual receptor. The value of $t_{T}$ is determined in the same manner as for the calculation of deposition rate [Hamby 1992].

Iodines. Iodine concentrations in the atmosphere are determined using,

$$
\chi_{i}\left[\frac{\mu C i}{m^{3}}\right]=\left\{\left(\frac{\chi_{D}}{Q} \cdot\left(1-F_{I}\right)\right)+\left(\frac{\chi_{D D}}{Q} \cdot F_{I} \cdot e^{31.62 t_{T}}\right)\right\}\left[\frac{\mathrm{sec}}{m^{3}}\right] \cdot Q_{i}\left[\frac{\mu C i}{s e c}\right] \cdot e^{\lambda_{i t}}
$$


where the $\chi_{D}$ represents a decayed concentration and $\chi_{D D}$ represents a decayed and depleted concentration. The factor in brackets calculates a weighted relative air concentration accounting for the deposition of the elemental fraction, $\mathrm{F}_{\mathrm{I}}$. The exponential term in brackets accounts for deposition equilibrium and is applied only to the depleted relative air concentration $\left(\chi_{\mathrm{DD}} / \mathrm{Q}\right)$. An exponential term is also added to account for radioactive decay during plume transit.

Other Nuclides. Air concentrations of the remaining nuclides (those not considered above), are calculated using,

$$
\chi_{i}\left[\frac{\mu \mathrm{Ci}}{\mathrm{m}^{3}}\right]=\frac{\chi_{\mathrm{DD}}}{\mathrm{Q}}\left[\frac{\mathrm{sec}}{\mathrm{m}^{3}}\right] \cdot \mathrm{Q}_{\mathrm{i}}\left[\frac{\mu \mathrm{Ci}}{\mathrm{sec}}\right] \cdot \mathrm{e}^{\left(31.62-\lambda_{\mathrm{i}} x_{\mathrm{T}}\right.}
$$

where all terms have been defined previously. Again, the positive rate coefficient in the exponential term (31.62 $\left.\mathrm{yr}^{-1}\right)$ compensates for the 8-day decay utilized in XOQDOQ's calculation of $\chi_{\mathrm{DD}} / \mathrm{Q}$.

\section{Nuclide Concentrations in Vegetation}

Tritium. A specific activity model describes the uptake of tritium in vegetation. Tritium concentrations in vegetation are determined directly from the concentrations of tritium in atmospheric moisture. Equilibrium is assumed to be achieved in a short time relative to an annual release. The concentration of tritium in vegetation, $\mathrm{C}_{T}^{v}$, is determined by,

$$
\mathrm{C}_{\mathrm{T}}^{\mathrm{v}}\left[\frac{\mu \mathrm{Ci}}{\mathrm{kg}}\right]=\frac{\chi_{\mathrm{T}}\left[\frac{\mu \mathrm{Ci}}{\mathrm{m}^{3}}\right] \cdot \mathrm{f}_{\mathrm{w}} \cdot \mathrm{R}}{\mathrm{H}\left[\frac{\mathrm{kg}}{\mathrm{m}^{3}}\right]}
$$

where $\chi_{T}$ is the atmospheric concentration, $\mathrm{f}_{\mathrm{w}}$ is the fraction of plant mass that is water, $R$ is the concentration ratio of plant tritium to atmospheric tritium, and $\mathrm{H}$ is the annual average absolute humidity. Studies [Bauer and Hamby, 1991; Hamby 1992] show that dose estimates for the vegetation consumption pathway are sensitive to the parameters in this model. A site-specific value has been developed for R [Hamby and Bauer 1994]. 
Carbon-14. The C-14 model for vegetation concentrations is similar to the tritium model. The equation,

$$
\mathrm{C}_{\mathrm{C}}^{v}\left[\frac{\mu \mathrm{Ci}}{\mathrm{kg}}\right]=\frac{\chi_{\mathrm{C}}\left[\frac{\mu \mathrm{Ci}}{\mathrm{m}^{3}}\right] \cdot \mathrm{F}_{\mathrm{t}} \cdot 0.11}{0.00016\left[\frac{\mathrm{kg}}{\mathrm{m}^{3}}\right]}
$$

is used to estimate $C-14$ vegetation concentrations, $C_{C}^{v}$. The parameter $F_{t}$ cannot exceed unity and is defined as the ratio of the total annual release time to the total annual time during which photosynthesis occurs (taken to be 4380 hours). If atmospheric releases occur more than half the year, the value of $F_{t}$ is 1.0. The fraction of total plant mass that is natural carbon is represented by 0.11 and 0.00016 is the concentration of natural carbon in the atmosphere.

Other Nuclides. The concentration of other nuclides in vegetation is determined using,

$$
C_{i}^{v}\left[\frac{\mu C i}{k g}\right]=d_{i}\left[\frac{\mu C i}{m^{2} y r}\right] \cdot\left\{\frac{r_{i}\left(1-e^{-\lambda_{i}^{w} b_{0}}\right)}{Y_{v}\left[\frac{\mathrm{kg}}{\mathrm{m}^{2}}\right] \lambda_{i}^{w}\left[\frac{1}{y r}\right]}+\frac{B_{i}^{v}\left(1-e^{-\lambda_{i} t_{b}}\right)}{P\left[\frac{\mathrm{kg}}{\mathrm{m}^{2}}\right] \lambda_{i}\left[\frac{1}{\mathrm{yr}}\right]}\right\} \cdot \mathrm{e}^{-\lambda_{i} \psi_{\mathrm{t}}}
$$

where $d_{i}$ is the deposition rate determined earlier, $r_{i}$ is the fraction of the nuclide deposited that remains on the surface of the plant, $\lambda_{i}^{*}$ represents losses by both weathering and radioactive decay, $t_{e}$ is the crop exposure time, $Y_{v}$ is the crop productivity, $B_{i}^{v}$ is the element-specific soil/plant uptake ratio, $\lambda_{i}$ is the radioactive decay constant, $t_{b}$ is the time over which the buildup of radionuclides occurs, $\mathrm{P}$ is the effective surface density of soil, and $t_{h}$ is the hold-up time after harvest (allowing for decay before consumption).

The two expressions in the brackets account for contamination via foliar deposition and root uptake, respectively. Radioiodines are assumed to be fully retained on vegetation while only $20 \%$ of other particulates are retained. The loss constant, $\lambda_{i}^{*}$, accounts for losses through physical weathering (14 day half-life) and radioactive decay. Values of $Y_{v}, t_{e}$, and $t_{h}$ vary depending on the type of crop and whether the vegetation is for human consumption or is to be used as fodder [Hamby 1991].

Concentrations in four types of vegetation are calculated in MAXINE: (1) leafy vegetables, (2) other vegetables, (3) pasture grass, and (4) stored feed. The values of 
three parameters in Equation 7 are different for the four concentration estimates, i.e., the

crop yield, $Y_{v}$, the exposure time, te, and the holdup time, $t_{h}$. Details on nominal values used for each input parameter can be found in Hamby [1992].

\section{Nuclide Concentrations in Meat and Milk}

All Nuclides. Concentrations of radionuclides in meat and milk are determined from feed concentrations, fodder intake rates, and element-specific feed transfer factors. Meat and milk concentrations are estimated using,

$$
C_{i}^{m}\left[\frac{\mu C i}{k g}\right]=C_{i}^{f o d d e r}\left[\frac{\mu C i}{k g}\right] \cdot F_{i}^{m}\left[\frac{d}{k g}\right] \cdot Q_{F}\left[\frac{k g}{d}\right] \cdot e^{\lambda_{i} \iota}
$$

where $C_{i}^{\text {fodder }}$ is the nuclide concentration in cattle feed (determined below), $F_{i}^{m}$ is the nuclide-specific feed transfer factor, $Q_{F}$ is the cattle feed rate. The exponential term accounts for the radiological decay time, $t_{s}$, between slaughter or milking and consumption where $\lambda_{i}$ is the nuclide-specific decay constant.

The nuclide concentration in fodder is estimated based on the fraction of time cattle spend on pasture and the fraction of that time that is spent consuming fresh pasture grass. The equation,

$$
C_{i}^{\text {fodder }}\left[\frac{\mu C i}{k g}\right]=f_{p} f_{s} C_{i}^{p}\left[\frac{\mu C i}{k g}\right]+\left\{f_{p}\left(1-f_{s}\right)+\left(1-f_{p}\right)\right\} C_{i}^{s}\left[\frac{\mu C i}{k g}\right]
$$

is used to calculate a fodder concentration by weighting the concentrations of pasture grass, $C_{i}^{p}$, and stored feed, $C_{i}^{s}$. The parameter $f_{p}$ is the fraction of time cattle spend on pasture and $f_{s}$ is the fraction of time that cattle eat fresh grass while on pasture.

Concentrations of nuclides in goat's milk are determined in the same manner as cow's milk and beef with the exception of varying the parameter values for feed consumption rate and the fraction of time spent consuming pasture grass while on pasture. 


\section{DOSIMETRY MODELS FOR ATMOSPHERIC RELEASES}

\section{Shine Dose}

Plume-Shine. Doses to offsite individuals from gamma shine are estimated in MAXINE only for the noble gases using an infinite plume model. The plume-shine dose from these nuclides has been determined to be significantly higher than doses resulting from other nuclides [USNRC 1977a]. The gamma dose from a particular noble gas in an atmospheric plume is calculated from,

$$
D_{i}^{p}\left[\frac{m r e m}{y r}\right]=\chi_{i}\left[\frac{\mu C i}{m^{3}}\right] \cdot S F \cdot D P_{i}^{p}\left[\frac{m_{r e m ~ m}^{3}}{y r \mu C i}\right]
$$

where SF is a shielding factor accounting for the fraction of time spent indoors and DF is the nuclide specific plume-shine dose factor. The receptor is assumed to be immersed in a homogeneous cloud with an atmospheric concentration, $\chi_{i}$, that is calculated for ground level. The value of SF is taken to be 0.7 [USNRC 1977a], meaning that the individual is assumed to be shielded from $30 \%$ of the external radiation.

Ground-Shine. Ground-shine doses are calculated for all particulate, gamma-emitting nuclides. The dose accounts for buildup over the plant lifetime and is given by,

$$
D_{i}^{g}\left[\frac{m r e m}{y r}\right]=d_{i}\left[\frac{\mu C i}{m^{2} y r}\right] \cdot S F \cdot D F_{i}^{\beta}\left[\frac{m^{2} r e m m^{2}}{y r \mu C i}\right] \cdot \frac{1-e^{-\lambda_{14}}}{\lambda_{i}}[y r]
$$

where $\mathrm{DF}_{\mathrm{i}}^{\mathrm{B}}$ is the nuclide-specific ground-shine dose factor and the exponential term accounts for the ground-surface buildup and subsequent radiological decay. The groundshine model contains the assumption that exposure is from an infinite plane source and the dose is calculated at 1 meter above the ground. Nuclide-specific doses are summed for the total dose. Again, the value of SF is assumed to be 0.7 . 


\section{Inhalation Dose}

Inhalation dose is determined for the maximum individual assuming a constant breathing rate and a constant concentration throughout the year of exposure. The nuclide-specific dose is estimated by,

$$
D_{i}^{\text {inh }}\left[\frac{\mathrm{mrem}}{\mathrm{yr}}\right]=\chi_{\mathrm{i}}\left[\frac{\mu \mathrm{Ci}}{\mathrm{m}^{3}}\right] \cdot \mathrm{BR}\left[\frac{\mathrm{m}^{3}}{\mathrm{yr}}\right] \cdot \mathrm{DF}_{\mathrm{i}}^{\mathrm{inh}}\left[\frac{\mathrm{mrem}}{\mu \mathrm{Ci}}\right]
$$

where $B R$ is the breathing rate and $D F_{i}^{i n h}$ is the nuclide-specific inhalation dose factor. $A$ breathing rate of $8000 \mathrm{~m}^{3} / \mathrm{yr}$ should be assumed for routine maximum individual dose estimates using MAXINE [USNRC 1977a].

\section{Food Ingestion Dose}

Dose to the maximum individual is estimated for ingestion of foodstuffs including vegetables, meat, and milk. Radionuclide intakes through the vegetation consumption pathway considers vegetables as being classified as either "leafy" or "other". "Other" includes fruits, grains, produce, and below ground vegetables. The dose via vegetable consumption is calculated using,

$$
D_{i}^{\text {veg }}\left[\frac{\text { mrem }}{y T}\right]=\left\{C_{i}^{v} U^{v} f_{v}+C_{i}^{1} U^{l} f_{l}\right\}\left[\frac{\mu C i}{y r}\right] \cdot D F_{i}^{\text {ing }}\left[\frac{m r e m}{\mu C i}\right]
$$

where $C_{i}^{v}$ and $C_{i}^{l}$ are radionuclide concentrations in leafy and other vegetables, $U^{v}$ and $U^{l}$ are consumption rates of the two vegetable clasifications, $f_{v}$ is the fraction of other vegetables that are home grown, and $f_{1}$ is the fraction of leafy vegetables consumed that originated in the home garden.

Individual dose from meat and milk consumption is calculated in the same manner, using,

$$
D_{i}^{m}\left[\frac{\text { nrem }}{y r}\right]=C_{i}^{m}\left[\frac{\mu C i}{k g}\right] \cdot U^{m}\left[\frac{k g}{y r}\right] \cdot D_{i}^{i n g}\left[\frac{m r e m}{\mu C i}\right]
$$

where the parameters have already been defined. All meat and milk consumed by the receptor, as specified by $U^{m}$, is assumed to be contaminated. The ingestion dose factor, 
$D F_{i}^{i n g}$, is nuclide-specific and is the same value for vegetable, meat, and milk consumption.

\section{ESTIMATING MAXIMUM INDIVIDUAL DOSE}

The MAXINE spreadsheet is EXCEL® based. Password protection has been applied so that the user can not access or overwrite the calculational models; the user only has access to the title, the input variables, and the source term. The spreadsheet can be copied to another user's computer, however, the password protection still exists on the original version and the copied version. On a computer with color capabilities, all cells whose contents are written in red are changeable.

Changes to the spreadsheet between assessments are minimal; only the first four dispersion factors and the receptor distance (see next section) need be modified for the routine analysis. Research using the spreadsheet is easily accomplished because the analyst has the ability to modify the input parameter values used in the concentration and dosimetry models.

\section{Input Required from XOQDOQ/PC}

Radiation doses estimated by MAXINE rely on the input of dispersion factors calculated by an independent computer routine. The MAXIGASP program, previously utilized for maximum individual dose estimates, combines the dispersion code XOQDOQ [Sagendorf et. al. 1982] with the dosimetry code GASPAR [Eckerman et. al. 1980]. MAXIGASP operates on the unclassified IBM mainframe. The MAXINE spreadsheet is essentially identical to GASPAR requiring input in the form of dispersion factors from XOQDOQ.

A PC version of $X O Q D O Q$ by the same name has been issued and is operational on an IBM-PC maintained by the Environmental Dosimetry Group. XOQDOQ/PC can be executed for various release scenarios and will calculate, for a given scenario, the four dispersion factors required by MAXINE. A procedure for executing XOQDOQ/PC is available in ETS Manual L15.16, Procedure No. EDG-11.

The transport models of XOQDOQ are described in the USNRC Regulatory Guide 1.111 [1977b] and have been verified by Bauer [1991]. Results from the PC version of 
XOQDOQ compare favorably with results from XOQDOQ resident on the IBM mainframe. The percent difference between dispersion factors calculated by $\mathrm{XOQDOQ} / \mathrm{PC}$ and the mainframe routine are given in Table 1 for ter release areas on the SRS. Blank spaces in Table 1 indicate that the difference in dispersion factors is less than $1 \%$ between $\mathrm{PC}$ and mainframe versions.

Table 1. Percent difference between dispersion factors calculated by the PC and mainframe versions of XOQDOQ (no value indicates agreement between dispersion factors).

\begin{tabular}{lcccc} 
& \multicolumn{4}{c}{ Percent Difference } \\
\cline { 2 - 4 } $\begin{array}{l}\text { Release } \\
\text { Location }\end{array}$ & $\chi / \mathrm{Q}$ & $\begin{array}{c}\text { Decayed } \\
\chi / \mathrm{Q}\end{array}$ & $\begin{array}{c}\text { Depleted } \\
\chi / \mathrm{Q}\end{array}$ & $\mathrm{D} / \mathrm{Q}$ \\
\hline & & & 2 & -12 \\
Center of Site & 8 & 2 & 10 & \\
A-Area & 11 & 10 & & -9 \\
C-Area & & & & \\
D-Area & & & 3 & -7 \\
F-Area & 4 & & 3 & \\
H-Area & & & & \\
K-Area & & -3 & & \\
L-Area & 2 & -2 & & \\
M-Area & -2 & & & \\
P-Area & & & & \\
\hline
\end{tabular}

A false indication of the accuracy of dispersion factors is reported in the mainframe version, i.e., to four significant digits. $\mathrm{XOQDOQ} / \mathrm{PC}$, more reasonably, reports the factors to two significant digits. This difference accounts for as much as $10 \%$ in results between the two programs. Other factors also play a role in causing the ratios to deviate from unity. For example, the mainframe version utilizes 21 distances in all sectors to define the terrain surface relative to the release point whereas the $\mathrm{PC}$ version allows the user only 10 distances. Both codes execute a linear interpolation routine to estimate terrain heights between defined distances, however, the PC version contains less detail 
and potentially results in a different input value for terrain height when estimating dispersion factors.

Dispersion factors vary between $-12 \%$ (D/Q relative to center-of-site release) and $11 \%$ ( $\chi / Q$ relative to A-Area release). More importantly, variations in estimates of the maximum individual doses resulting from the use oi these dispersion factors have been calculated and are presented in a later section.

\section{Bench Mark}

Bench marking calculations have been performed for all concentration and dose models utilized in the MAXINE spreadsheet. These calculations are shown in Appendix A for cesium-137. A comparison of these calculations to the bench marking run of MAXINE (also in Appendix A) shows that the models for Cs-137 are being executed properly.

\section{Comparison to MAXIGASP}

The dosimetry models contained in MAXINE have been shown to produce identical results to MAXIGASP [Hamby 1992]. These comparisons were accomplished using the dispersion factors calculated in the MAXIGASP run. The effect of obtaining the dispersion factors from $\mathrm{XOQDOQ/PC}$ has been investigated by calculating differences between nuclide doses estimated using the PC and mainframe versions of XOQDOQ.

The percent difference between doses calculated using the two methodologies has been calculated for each nuclide and release location (see Table 1). The comparisons are shown in Appendix B. Nuclides that are released to the atmosphere from routine operations at the SRS (without reactor operations) are indicated by the arrow in the rightmost column. Percent differences in dose calculations for nuclides released from the SRS indicate a good comparison between PC and mainframe results.

Over all nuclides considered, differences range from $-13 \%$ to $43 \%$. Nuclide doses resulting in the largest differences have very short half-lives. These differences are due to variations in decay times resulting from differences in transport time calculations.

Appendix B contains differences (as a percentage) among dispersion factors and among doses for all ten release locations. Of the nuclides released from the SRS on a regular 
basis, over all ten release locations, none have differences greater than $12 \%$. These differences are found for releases from the center of the SRS and are the result of the $12 \%$ difference in the estimation of relative deposition rate calculated using the two dispersion programs. Considering the uncertainties involved in dose assessment, differences of this magnitude are acceptable. The methodology established here for estimating dose to the maximum individual is, therefore, replacing previous methods using MAXIGASP on the IBM mainframe.

\section{Summary of Input Parameters}

Values for each parameter utilized in the MAXINE spreadsheet are given below. A user entry outside the valid range will result in an error message, but the calculation will continue. The expected value is that suggested by data from site-specific studies or the literature. Dose factors utilized in the calculation of atmospheric dose were derived using ICRP 30 methodology and are taken from DOE publications [USDOE 1988a; 1988b].

Relative Concentration $(\mathrm{X} / \mathrm{Q})\left[\mathrm{sec} \mathrm{m}^{-3}\right]$ :

\section{Decayed X/Q $\left[\mathrm{sec} \mathrm{m}^{-3}\right]$ :}

Decayed \& Depleted X/Q [ $\left.\mathrm{sec} \mathrm{m}^{-3}\right]$ :
Relative air concentration without radioactive decay and without depletion. Value taken from XOQDOQ/PC output. Valid Range: $1 \times 10^{-5}$ to $1 \times 10^{-10} \mathrm{sec} \mathrm{m}^{-3}$

Relative air concentration assuming a 2.26 day decay but no plume depletion. Value taken from XOQDOQ/PC output. Valid Range: $1 \times 10^{-5}$ to $1 \times 10^{-10} \mathrm{sec} \mathrm{m}^{-3}$

Relative air concentration assuming an 8 day decay and plume depletion. Value taken from XOQDOQ/PC output. Valid Range: $1 \times 10^{-5}$ to $1 \times 10^{-10} \mathrm{sec} \mathrm{m}^{-3}$

Relative Deposition $(\mathrm{D} / \mathrm{Q})\left[\mathrm{m}^{-2}\right]$ :

Relative deposition of particulates without radioactive decay. Value taken from XOQDOQ/PC output.

Valid Range: $1 \times 10^{-8}$ to $1 \times 10^{-13} \mathrm{~m}^{-2}$

Distance to Receptor: Distance from the release point to the downwind location of the maximum individual (usually at the site boundary). Value taken from XOQDOQ/PC output. Valid Range: $0-80000 \mathrm{~m}$ 
Vegetable Consumption:

Leafy Veg. Consumption:

Vegetable consumption rate for the assessment individual. The average consumption rate is $163 \mathrm{~kg} / \mathrm{yr}$ and maximum consumption rate is $276 \mathrm{~kg} / \mathrm{yr}$.

Valid Response: AVG, MAX, or Value between 0 and $900 \mathrm{~kg} \mathrm{yr}^{-1}$

Expected Value: MAX

Leafy vegetable consumption rate for the assessment individual. The average consumption rate is $21 \mathrm{~kg} / \mathrm{yr}$ and the maximum consumption rate is $43 \mathrm{~kg} / \mathrm{yr}$. Valid Response: AVG, MAX, or Value between 0 and $260 \mathrm{~kg} \mathrm{yr}^{-1}$ Expected Value: MAX

Milk Consumption: Milk consumption rate for the assessment individual. The average consumption rate is $120 \mathrm{~L} / \mathrm{yr}$ and the maximum consumption rate is $230 \mathrm{~L} / \mathrm{yr}$.

Valid Response: AVG, MAX, or Value between 0 and $500 \mathrm{~L} \mathrm{yr}^{-1}$ Expected Value: MAX

Meat Consumption: Meat consumption rate for the assessment individual. The average consumption rate is $43 \mathrm{~kg} / \mathrm{yr}$ and the maximum consumption rate is $81 \mathrm{~kg} / \mathrm{yr}$.

Valid Response: AVG, MAX, or Value between 0 and $470 \mathrm{~kg} \mathrm{yr}^{-1}$

Expected Value: MAX

Origin of Milk: Type of milk consumed by maximum individual. Enter either COW or GOAT and check the three parameters (in BOLD), "Feed Consumption", "Fraction of Year on Pasture (milk)", and "Fraction Intake from Pasture (milk)". These parameters will need to be changed depending on the type of milk chosen.

Deposition Buildup Time [yr]: Time of buildup on soil; used to estimate vegetation concentrations through the soil uptake pathway.

Valid Range: 0 - 100 yr

Expected Value: plant lifetime

Breathing Rate $\left[\mathrm{m}^{3} \mathrm{yr}^{-1}\right]$ : Annual average breathing rate of maximum individual. Reg. Guide 1.109 specifies 8000 $\mathrm{m}^{3} / \mathrm{yr}$ while ICRP 23 (Standard Man) specifies $8400 \mathrm{~m}^{3} / \mathrm{yr}$.

Valid Range: $6000-10000 \mathrm{~m}^{3} \mathrm{yr}^{-1}$

Expected Value: $8000 \mathrm{~m}^{3} \mathrm{yr}^{-1}$ 
Elemental Iodine Fraction: Fraction of iodine released that is in the elemental form; the balance is assumed to behave as a gas. The elemental iodine deposits on vegetation and is essentially treated as a particulate.

Valid Range: 0 - 1

Expected Value: 1

Absolute Humidity $\left[\mathrm{kg} \mathrm{m}^{-3}\right]$ :

Annual average absolute humidity in the vicinity of the SRS. Parameter used in the estimation of tritium concentrations in vegetation. NRC default is $0.008 \mathrm{~kg} / \mathrm{m}^{3}$. Valid Range: $0.003-0.020 \mathrm{~kg} \mathrm{~m}^{-3}$

Expected Value: $0.01125 \mathrm{~kg} \mathrm{~m}^{-3}$

Tritium Plant-to-Air Ratio: Ratio of tritium concentration in plant moisture to tritium concentration in atmospheric moisture. Determined for the SRS by Hamby and Bauer [1993].

Valid Range: 0 - 5

Expected Value: 0.54

Shielding Factor: Fraction of time that the maximum individual is exposed to gamma radiation from plume and ground sources.

Valid Range: $0-1$

Expected Value: 0.70

Fraction of Year C-14 Released: The ratio of the total annual release time (for C-14 releases) to the total annual time during which photosynthesis occurs (taken to be 4400 hours). If the total annual release time is greater than 4400 hours (or continuous), this fraction is taken to be unity.

Valid Range: 0 - 1

Expected Value: 1

Retained Fraction (iodines): The fraction of elemental iodine that is retained on the surface of vegetation following foliar deposition.

Valid Range: 0 - 1

Expected Value: 1

Retained Fraction (particulates): The fraction of particulates (other than iodine) that are retained on the surface of vegetation following foliar deposition. Expected value is taken from USNRC [1977a]. Valid Range: 0 - 1

Expected Value: 0.20 
Weathering Rate Constant $\left[\mathrm{yr}^{-1}\right]$ :

Crop Exposure Time [yr]:
Rate constant describing the exponential removal of particulates from plant surfaces due to weathering (including radioactive decay for short-lived radionuclides). Expected value (14 day half-life) is taken from USNRC [1977a]. The valid range spans a 1 to 30 day half-life.

Valid Range: 5 - $250 \mathrm{yr}^{-1}$

Expected Value: $18.1 \mathrm{yr}^{-1}$

Average time during growing season that edible crops are exposed to atmospheric deposition. Expected value (70 days) is from Hamby [1991].

Valid Range: 0 - 1 yr

Expected Value: $0.192 \mathrm{yr}$

Pasture Grass Exposure Time [yr]:

Average time during growing season that bermuda grass is exposed to atmospheric deposition. Expected value (30 days) is from Hamby [1991].

Valid Range: 0 - 1 yr

Expected Value: $0.0822 \mathrm{yr}$

Pasture Grass Productivity [kg m-2]:

Mass density of bermuda grass; used to calculate deposition contamination on grass. Expected value determined by Hamby [1991].

Valid Range: 0 - $3 \mathrm{~kg} \mathrm{~m}^{-2}$

Expected Value: $1.8 \mathrm{~kg} \mathrm{~m}^{2}$

Produce Productivity $\left[\mathrm{kg} \mathrm{m}^{-2}\right]$ : $\quad$ Mass density of above-ground edible crops; used to calculate deposition contamination on plant surfaces. Expected value determined by Hamby [1991].

Valid Range: 0 - $3 \mathrm{~kg} \mathrm{~m}^{-2}$

Expected Value: $0.7 \mathrm{~kg} \mathrm{~m}^{-2}$

Surface Density of Soil $\left[\mathrm{kg} \mathrm{m}^{-2}\right]$ : soil; the product of the bulk soil density and the contaminated soil depth. Expected value calculated from soil density of $1600 \mathrm{~kg} \mathrm{~m}^{3}$ and a soil depth of $0.15 \mathrm{~m}$.

Valid Range: 50 - $400 \mathrm{~kg} \mathrm{~m}^{-2}$

Expected Value: $240 \mathrm{~kg} \mathrm{~m}^{-2}$ 
Pasture Grass Holdup Time [yr]:

Stored Feed Holdup Time [yr]:

Leafy Vegetable Holdup Time [yr]:

Produce Holdup Time [yr]:

Feed Consumption (milk) $\left[\mathrm{kg} \mathrm{d}^{-1}\right]$ :

Feed Consumption (beef) $\left[\mathrm{kg} \mathrm{d}^{-1}\right]$ :

Feed-Milk-Man Transport Time [yr]:
Radiological decay time between deposition of particulates on pasture grass and consumption of grass by cattle. Year-round grazing and a constant release rate result in a pasture grass holdup time of zero.

Valid Range: $0-1$ yr

Expected Value: 0 yr

Radiological decay time from harvest of pasture grass to consumption by cattle. The expected value is 90 days.

Valid Range: 0 - 1 yr

Expected Value: 0.247 yr

Radiological decay time between harvest of leafy vegetables and human consumption. Individuals are assumed to grow leafy vegetables in their own gardens. Therefore, the expected value (1 day) is relatively short. Valid Range: 0 - 1 yr

Expected Value: 0.00274 yr

Radiological decay time between harvest of edible produce and human consumption. For the maximum individual, produce is assumed to be obtained from the market where the average holdup time is relatively long (60 days).

Valid Range: 0 - 1 yr

Expected Value: $0.164 \mathrm{yr}$

Milk-cattle or goat consumption rate of fodder. This parameter description will change in MAXINE depending on the entry for "Origin of Milk". Expected value from T. Mathis, Aiken County extension agent.

Valid Range: 0 - $100 \mathrm{~kg} \mathrm{~d}^{-1}$

Expected Value (goat): $6 \mathrm{~kg} \mathrm{~d}^{-1}$

Expected Value (cow): $52 \mathrm{~kg} \mathrm{~d}^{-1}$

Beef-cattle consumption rate of fodder.

Expected value from T. Mathis, Aiken Co. extension agent.

Valid Range: 0 - $100 \mathrm{~kg} \mathrm{~d}^{-1}$

Expected Value: $36 \mathrm{~kg} \mathrm{~d}^{-1}$

Radiological decay time from the consumption of fodder by milk-cattle or goats to the consumption of milk by man. Expected value is 3 days, determined by Hamby [1991].

Valid Range: $0-0.038$ yr

Expected Value: $0.00822 \mathrm{yr}$ 
Fraction of year on Pasture (beef):

Self explanatory; for beef cattle.

Valid Range: 0 - 1

Expected Value: 1

Fraction of year on Pasture (milk): Self explanatory; for goats or milk cattle.

Valid Range: 0 - 1

Expected Value (goat): 0.79

Expected Value (cow): 1.00

Fractional Intake from Pasture (beef): Fraction of a beef-cattle's diet that is pasture grass while the cow is on pasture.

Valid Range: 0 - 1

Expected Value: 0.75

Fractional Intake Pasture (milk): Fraction of a goat or milk-cattle's diet that is pasture grass while on pasture.

Valid Range: 0 - 1

Expected Value (goat): 0.85

Expected Value (cow): 0.56

Slaughter to Consumption Time [yr]: $\quad$ Radiological decay time between the slaughter of a beef-cattle and human consumption. Expected value (6 days) taken from Hamby [1991].

Valid Range: 0 - $0.038 \mathrm{yr}$

Expected Value: $0.0164 \mathrm{yr}$

Fraction of Produce from Garden: Fraction of produce consumed that was grown in local garden. The balance of produce is not contaminated.

Valid Range: 0 - 1

Expected Value: 0.76

Frac. of Leafy Veg. from Garden:

Fraction of leafy vegetables consumed that were grown in local garden. The balance of leafy vegetables are not contaminated.

Valid Range: 0 - 1

Expected Value: 1 


\section{REFERENCES}

Bauer, L.R. Modelling chronic atmospheric releases at the SRS: Evaluation and verification of XOQDOQ. Westinghouse Savannah River Company. Aiken, SC: Report No. WSRC-RP-91-320; 1991.

Bauer, L.R.; Hamby, D.M. Relative sensitivities of existing and novel model parameters in atmospheric tritium dose estimates. Rad. Prot. Dosimetry. 37:253-260; 1991.

Eckerman, K.F.; Congel, F.J.; Roecklein, A.K.; Pasciak, W.J. User's guide to GASPAR code. U.S. Nuclear Regulatory Commission. Washington, DC: Report No. NUREG/0597; 1980.

Hamby, D.M. Land and water-use characteristics in the vicinity of the Savannah River Site. Westinghouse Savannah River Company. Aiken, SC: Report No. WSRC-RP-91-17; 1991.

Hamby, D.M. Verification of the GASPAR dose assessment module used in MAXIGASP and POPGASP. Westinghouse Savannah River Company, Aiken, SC: Report No. WSRC-RP-92-418; 1992.

Hamby, D.M. A probabilistic estimation of atmospheric tritium dose. Health Phys. 65(1):33-40; 1993.

Hamby, D.M.; Bauer, L.R. The vegetation-to-air concentration ratio in a specific activity atmospheric tritium model. to appear in Health Phys. 66(3); March 1994.

Sagendorf, J.F.; Goll, J.T.; Sandusky, W.F. XOQDOQ: Computer program for the meteorological evaluation of routine effluent releases at nuclear power stations. U.S. Nuclear Regulatory Commission. Washington, DC: Report No. NUREG/CF-2919; 1982.

U.S. Department of Energy. External dose-rate conversion factors for calculation of dose to the public. Washington, DC: Report No. DOE/EH-0070; 1988.

U.S. Department of Energy. Internal dose conversion factors for calculation of dose to the public. Washington, DC: Report No. DOE/EH-0071; 1988.

U.S. Nuclear Regulatory Commission. Calculation of annual doses to man from routine releases of reactor effluents for the purpose of evaluating compliance with 10 CFR Part 50, Appendix I. Washington, DC: Regulatory Guide 1.109, Rev. 1; 1977a.

U.S. Nuclear Regulatory Commission. Methods for estimating atmospheric transport and dispersion of gaseous effluents in routine releases from light-water-cooled reactors. Washington, DC: Regulatory Guide 1.111, Rev. 1; 1977b.

Weber, A.H. Comparison of Savannah River Site's meteorological databases. Westinghouse Savannah River Company. Aiken, SC: Report No. WSRC-RP-93-269; 1993. 



\section{MAXINE}

\section{Bench Marking Calculations \\ (all calculations are for Cs-137)}

The following is an example calculation of the MAXINE spreadsheet for Cs-137. This appendix also contains the MAXINE output for the bench mark case. Input parameter values for each variable can be extracted from the MAXINE printout.

A Deposition Rate:

$$
\begin{aligned}
& \mathrm{d}_{\mathrm{i}}\left[\frac{\mu \mathrm{Ci}}{\mathrm{m}^{2} \mathrm{yr}}\right]=\frac{\mathrm{D}}{\mathrm{Q}}\left[\frac{1}{\mathrm{~m}^{2}}\right] \cdot \mathrm{Q}_{\mathrm{i}}\left[\frac{\mu \mathrm{Ci}}{\mathrm{yr}}\right] \cdot \mathrm{e}^{\left(31.62-\lambda_{\mathrm{i}} \mathrm{t}_{\mathrm{T}}\right.} \\
& \mathrm{d}_{\mathrm{i}}=\left(3.3 \times 10^{-11} \mathrm{~m}^{-2}\right)\left(1 \times 10^{6} \mathrm{mCi} \mathrm{yr}^{-1}\right) \operatorname{EXP}\left[\left(31.62-0.0225 \mathrm{yr}^{-1}\right)\left(7.83 \times 10^{-6} \mathrm{yr}\right)\right] \\
& \mathrm{d}_{\mathrm{i}}=3.3 \times 10^{-5} \mathrm{mCi} \mathrm{m}^{-2} \mathrm{yr}^{-1}
\end{aligned}
$$

where,

$$
\begin{aligned}
\mathrm{t}_{\mathrm{T}} & =\frac{\mathrm{D}[\mathrm{m}]}{4.05\left[\frac{\mathrm{m}}{\mathrm{s}}\right] \cdot 31536000\left[\frac{\mathrm{s}}{\mathrm{yr}}\right]} \\
\mathrm{t}_{\mathrm{T}} & =1000 \mathrm{~m} / 1.28 \times 10^{8} \mathrm{~m} \mathrm{yr}^{-1}=7.83 \times 10^{-6} \mathrm{yr}
\end{aligned}
$$

B Atmospheric Concentration:

$$
\begin{aligned}
& \chi_{i}\left[\frac{\mu \mathrm{Ci}}{\mathrm{m}^{3}}\right]=\frac{\chi_{\mathrm{DD}}}{\mathrm{Q}}\left[\frac{\mathrm{sec}}{\mathrm{m}^{3}}\right] \cdot \mathrm{Q}_{\mathrm{i}}\left[\frac{\mu \mathrm{Ci}}{\mathrm{sec}}\right] \cdot \mathrm{e}^{\left(31.62-\lambda_{j} \mathrm{t}_{\mathrm{T}}\right.} \\
& =\left(6.1 \times 10^{-9} \mathrm{sec} \mathrm{m}^{-3}\right)\left(0.0317 \mathrm{mCi} \mathrm{sec}^{-1}\right) \operatorname{EXP}\left[\left(31.62-0.0225 \mathrm{yr}^{-1}\right)\left(7.83 \times 10^{-6} \mathrm{yr}\right)\right] \\
& =1.9 \times 10^{-10} \mathrm{mCi} \mathrm{m}^{-3}
\end{aligned}
$$


C Nuclide Concentration in Other Vegetables:

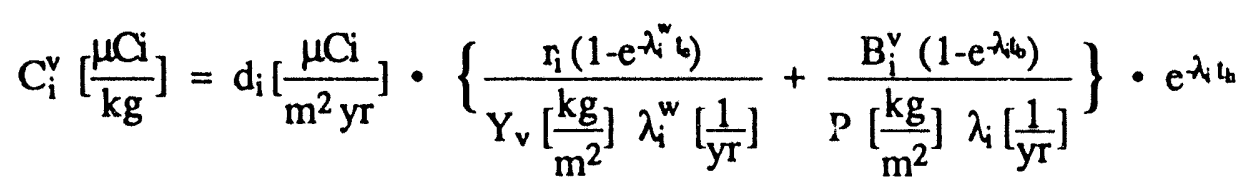

where,

$$
\begin{aligned}
& \frac{\mathrm{r}_{\mathrm{i}}\left(1-\mathrm{e}^{\left.-\lambda_{i}^{N} \mathrm{~b}_{0}\right)}\right.}{\mathrm{Y}_{\mathrm{v}}\left[\frac{\mathrm{kg}}{\mathrm{m}^{2}}\right] \lambda_{\mathrm{i}}^{\mathrm{w}}\left[\frac{1}{\mathrm{yr}}\right]}=\frac{0.2\left[1-\mathrm{e}^{\left.-\left(18.1+0.0225 \mathrm{yr}^{-1}\right)(0.192 \mathrm{yr})\right]}\right.}{\left(0.7 \mathrm{~kg} \mathrm{~m}^{-2}\right)\left(18.1+0.0225 \mathrm{yr}^{-1}\right)}=0.0153 \mathrm{~m}^{2} \mathrm{yr} \mathrm{kg}^{-1} \\
& \frac{\mathrm{B}_{\mathrm{i}}^{\mathrm{v}}\left(1-\mathrm{e}^{-\lambda \mathrm{fb}_{6}}\right)}{\mathrm{P}\left[\frac{\mathrm{kg}}{\mathrm{m}^{2}}\right] \lambda_{\mathrm{i}}\left[\frac{1}{\mathrm{yr}}\right]}=\frac{0.01\left[1-\mathrm{e}^{-\left(0.0225 \mathrm{yr}^{-1}\right)(38 \mathrm{yr})}\right]}{\left(240 \mathrm{~kg} \mathrm{~m}^{-2}\right)\left(0.0225 \mathrm{yr}^{-1}\right)}=0.00106 \mathrm{~m}^{2} \mathrm{yr} \mathrm{kg}^{-1} \\
& =\left(3.3 \times 10^{-5} \mathrm{mCi} \mathrm{m}^{-2} \mathrm{yr}^{-1}\right)(0.0153+0.00106) \operatorname{EXP}\left[-\left(0.0225 \mathrm{yr}^{-1}\right)(0.164 \mathrm{yr})\right] \\
& =5.4 \times 10^{-7} \mathrm{mCi} \mathrm{kg}^{-1}
\end{aligned}
$$

D Nuclide Concentration in Leafy Vegetables:

$$
C_{i}^{v}\left[\frac{\mu C i}{k g}\right]=d_{i}\left[\frac{\mu C i}{m^{2} y r}\right] \cdot\left\{\frac{r_{i}\left(1-e^{\lambda_{i}^{w} b}\right)}{Y_{v}\left[\frac{\mathrm{kg}}{m^{2}}\right] \lambda_{i}^{w}\left[\frac{1}{y r}\right]}+\frac{B_{i}^{v}\left(1-e^{\lambda_{m}}\right)}{P\left[\frac{k g}{m^{2}}\right] \lambda_{i}\left[\frac{1}{y r}\right]}\right\} \cdot e^{\lambda_{1} b_{b}}
$$

where,

$$
\begin{aligned}
& \frac{\mathrm{r}_{\mathrm{i}}\left(1-\mathrm{e}^{-\lambda_{\mathrm{i}}^{\mathrm{L}} \mathrm{b}}\right)}{\mathrm{Y}_{\mathrm{v}}\left[\frac{\mathrm{kg}}{\mathrm{m}^{2}}\right] \lambda_{\mathrm{i}}^{\mathrm{w}}\left[\frac{1}{\mathrm{yr}}\right]}=\frac{0.2\left[1-\mathrm{e}^{-\left(18.1+0.0225 \mathrm{yr}^{-1}\right)(0.192 \mathrm{yr})}\right]}{\left(0.7 \mathrm{~kg} \mathrm{~m}^{-2}\right)\left(18.1+0.0225 \mathrm{yr}^{-1}\right)}=0.0153 \mathrm{~m}^{2} \mathrm{yr} \mathrm{kg}^{-1} \\
& \frac{\mathrm{B}_{\mathrm{i}}^{\mathrm{v}}\left(1-\mathrm{e}^{\left.-\lambda_{\mathrm{t}}\right)}\right)}{\mathrm{P}\left[\frac{\mathrm{kg}}{\mathrm{m}^{2}}\right] \lambda_{\mathrm{i}}\left[\frac{1}{\mathrm{yr}}\right]}=\frac{0.01\left[1-\mathrm{e}^{-\left(0.0225 \mathrm{yr}^{-1}\right)(38 \mathrm{yr})}\right]}{\left(240 \mathrm{~kg} \mathrm{~m}^{-2}\right)\left(0.0225 \mathrm{yr}^{-1}\right)}=0.00106 \mathrm{~m}^{2} \mathrm{yr} \mathrm{kg}^{-1} \\
& =\left(3.3 \times 10^{-5} \mathrm{mCi} \mathrm{m}^{-2} \mathrm{yr}^{-1}\right)(0.0153+0.00106) \operatorname{EXP}\left[-\left(0.0225 \mathrm{yr}^{-1}\right)(0.00274 \mathrm{yr})\right] \\
& =5.4 \times 10^{-7} \mathrm{mCi} \mathrm{kg}^{-1}
\end{aligned}
$$


E Nuclide Concentration in Pasture Grass:

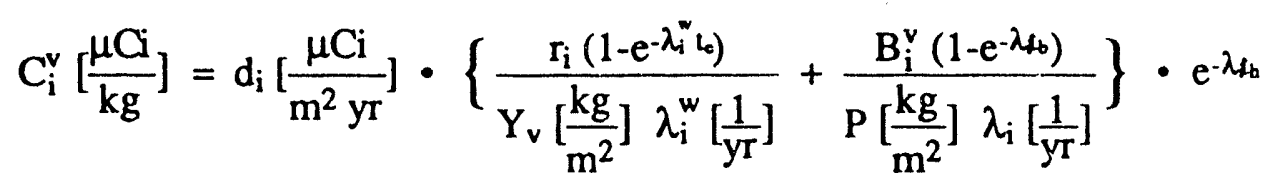

where,

$$
\begin{aligned}
& \frac{\mathrm{r}_{\mathrm{i}}\left(1-\mathrm{e}^{-\lambda_{i}^{\mathrm{N}} \mathrm{b}_{0}}\right)}{\mathrm{Y}_{\mathrm{v}}\left[\frac{\mathrm{kg}}{\mathrm{m}^{2}}\right] \lambda_{\mathrm{i}}^{\mathrm{w}}\left[\frac{1}{\mathrm{yr}}\right]}=\frac{0.2\left[1-\mathrm{e}^{-\left(18.1+0.0225 \mathrm{yr}^{-1}\right)(0.0822 \mathrm{yr})}\right]}{\left(1.8 \mathrm{~kg} \mathrm{~m}^{-2}\right)\left(18.1+0.0225 \mathrm{yr}^{-1}\right)}=0.00475 \mathrm{~m}^{2} \mathrm{yr} \mathrm{kg}^{-1} \\
& \frac{\mathrm{B}_{\mathrm{i}}^{\mathrm{v}}\left(1-\mathrm{e}^{-\lambda \mathrm{fb}_{6}}\right)}{\mathrm{P}\left[\frac{\mathrm{kg}}{\mathrm{m}^{2}}\right] \lambda_{\mathrm{i}}\left[\frac{1}{\mathrm{yr}}\right]}=\frac{0.01\left[1-\mathrm{e}^{-\left(0.0225 \mathrm{yr}^{-1}\right)(38 \mathrm{yr})}\right]}{\left(240 \mathrm{~kg} \mathrm{~m}^{-2}\right)\left(0.0225 \mathrm{yr}^{-1}\right)}=0.00106 \mathrm{~m}^{2} \mathrm{yr} \mathrm{kg}^{-1} \\
& =\left(3.3 \times 10^{-5} \mathrm{mCi} \mathrm{m}^{-2} \mathrm{yr}^{-1}\right)(0.00475+0.00106) \operatorname{EXP}\left[-\left(0.0225 \mathrm{yr}^{-1}\right)(0 \mathrm{yr})\right] \\
& =1.9 \times 10^{-7} \mathrm{mCi} \mathrm{kg}^{-1}
\end{aligned}
$$

F Nuclide Concentration in Stored Feed:

$$
C_{i}^{v}\left[\frac{\mu C i}{k g}\right]=d_{i}\left[\frac{\mu C i}{m^{2} y r}\right] \cdot\left\{\frac{r_{i}\left(1-e^{-\lambda_{i}^{N} t_{b}}\right)}{Y_{v}\left[\frac{k g}{m^{2}}\right] \lambda_{i}^{w}\left[\frac{1}{y r}\right]}+\frac{B_{i}^{v}\left(1-e^{-\lambda t_{b}}\right)}{P\left[\frac{k g}{m^{2}}\right] \lambda_{i}\left[\frac{1}{y r}\right]}\right\} \cdot e^{-\lambda f_{b}}
$$

where,

$$
\begin{aligned}
& \frac{\mathrm{r}_{\mathrm{i}}\left(1-\mathrm{e}^{-\lambda_{i}^{\mathrm{N}} \mathrm{b}_{0}}\right)}{\mathrm{Y}_{\mathrm{v}}\left[\frac{\mathrm{kg}}{\mathrm{m}^{2}}\right] \lambda_{\mathrm{i}}^{\mathrm{w}}\left[\frac{1}{\mathrm{yr}}\right]}=\frac{0.2\left[1-\mathrm{e}^{\left.-\left(18.1+0.0225 \mathrm{yr}^{-1}\right)(0.192 \mathrm{yr})\right]}\right.}{\left(0.7 \mathrm{~kg} \mathrm{~m}^{-2}\right)\left(18.1+0.0225 \mathrm{yr}^{-1}\right)}=0.0153 \mathrm{~m}^{2} \mathrm{yr} \mathrm{kg}^{-1} \\
& \frac{\mathrm{B}_{\mathrm{i}}^{\mathrm{v}}\left(1-\mathrm{e}^{\left.-\lambda_{\mathrm{t}}\right)}\right.}{\mathrm{P}\left[\frac{\mathrm{kg}}{\mathrm{m}^{2}}\right] \lambda_{\mathrm{i}}\left[\frac{1}{\mathrm{yr}}\right]}=\frac{0.01\left[1-\mathrm{e}^{-\left(0.0225 \mathrm{yr}^{-1}\right)(38 \mathrm{yr})}\right]}{\left(240 \mathrm{~kg} \mathrm{~m}^{-2}\right)\left(0.0225 \mathrm{yr}^{-1}\right)}=0.00106 \mathrm{~m}^{2} \mathrm{yr} \mathrm{kg}^{-1} \\
& =\left(3.3 \times 10^{-5} \mathrm{mCi} \mathrm{m}^{-2} \mathrm{yr}^{-1}\right)(0.0153+0.00106) \operatorname{EXP}\left[-\left(0.0225 \mathrm{yr}^{-1}\right)(0.247 \mathrm{yr})\right] \\
& =5.4 \times 10^{-7} \mathrm{mCi} \mathrm{kg}^{-1}
\end{aligned}
$$


G Nuclide Concentration in Dairy Cattle Fodder:

$$
\begin{aligned}
& C_{i}^{\text {fodder }}\left[\frac{\mu C i}{k g}\right]=f_{p} f_{s} C_{i}^{p}\left[\frac{\mu C i}{k g}\right]+\left\{f_{p}\left(1-f_{s}\right)+\left(1-f_{p}\right)\right\} C_{i}^{6}\left[\frac{\mu C i}{k g}\right] \\
&=(1.00)(0.56)\left(1.9 \times 10^{-7} \mathrm{mCi} \mathrm{kg}^{-1}\right)+ \\
&\{(1.00)(1-0.56)+(1-1.00)\}\left(5.4 \times 10^{-7} \mathrm{mCi} \mathrm{kg}^{-1}\right) \\
&= 3.4 \times 10^{-7} \mathrm{mCi} \mathrm{kg}^{-1}
\end{aligned}
$$

H Nuclide Concentration in Beef Cattle Fodder:

$$
\begin{aligned}
& C_{i}^{\text {fodder }}\left[\frac{\mu C i}{k g}\right]=f_{p} f_{s} C_{i}^{p}\left[\frac{\mu C i}{k g}\right]+\left\{f_{p}\left(1-f_{s}\right)+\left(1-f_{p}\right)\right\} C_{i}^{6}\left[\frac{\mu C i}{k g}\right] \\
&=(1.00)(0.75)\left(1.9 \times 10^{-7} \mathrm{mCi} \mathrm{kg}^{-1}\right)+ \\
&\{(1.00)(1-0.75)+(1-1.00)\}\left(5.4 \times 10^{-7} \mathrm{mCi} \mathrm{kg}^{-1}\right) \\
&= 2.8 \times 10^{-7} \mathrm{mCi} \mathrm{kg}^{-1}
\end{aligned}
$$

I Nuclide Concentration in Milk:

$$
\begin{aligned}
& C_{i}^{m}\left[\frac{\mu C i}{L}\right]=C_{i}^{\text {fodder }}\left[\frac{\mu C i}{k g}\right] \cdot F_{i}^{m}\left[\frac{d}{L}\right] \cdot Q_{r}\left[\frac{k g}{d}\right] \cdot e^{-\lambda t_{s}} \\
& =\left(3.4 \times 10^{-7} \mathrm{mCi} \mathrm{kg}^{-1}\right)\left(0.012 \mathrm{~d} \mathrm{~L}^{-1}\right)\left(52 \mathrm{~kg} \mathrm{~d}^{-1}\right) \operatorname{EXP}\left[-\left(0.0225 \mathrm{yr}^{-1}\right)(0.00822 \mathrm{yr})\right] \\
& =2.1 \times 10^{-7} \mathrm{mCi} \mathrm{L}^{-1}
\end{aligned}
$$

J Nuclide Concentration in Meat:

$$
\begin{aligned}
& C_{i}^{m}\left[\frac{\mu C i}{k g}\right]=C_{i}^{f o d d e r}\left[\frac{\mu C i}{k g}\right] \cdot F_{i}^{m}\left[\frac{d}{k g}\right] \cdot Q_{F}\left[\frac{\mathrm{kg}}{d}\right] \cdot e^{\lambda i_{i}} \\
& =\left(2.8 \times 10^{-7} \mathrm{mCi} \mathrm{kg}^{-1}\right)\left(0.004 \mathrm{~d} \mathrm{~kg}^{-1}\right)\left(36 \mathrm{~kg} \mathrm{~d}^{-1}\right) \operatorname{EXP}\left[-\left(0.0225 \mathrm{yr}^{-1}\right)(0.0164 \mathrm{yr})\right] \\
& =4.0 \times 10^{-8} \mathrm{mCi} \mathrm{kg}^{-1}
\end{aligned}
$$


K Individual Shine Dose (ground shine):

$$
\begin{aligned}
& D_{i}^{g}\left[\frac{m r e m}{y r}\right]=d_{i}\left[\frac{\mu C i}{m^{2} y r}\right] \cdot S F \cdot D F_{i}^{g}\left[\frac{\mathrm{mrem} \mathrm{m}^{2}}{y r \mu C i}\right] \cdot \frac{1-e^{-\lambda t_{t b}}}{\lambda_{i}}[y r] \\
&=\left(3.3 \times 10^{-5} \mathrm{mCi} \mathrm{m}^{-2} \mathrm{yr}^{-1}\right)(0.7)\left(57.8 \mathrm{mrem} \mathrm{m}^{2} \mathrm{yr}^{-1} \mathrm{mCi}^{-1}\right) \\
&\left.\left(1-\mathrm{EXP}_{-}-\left(0.0225 \mathrm{yr}^{-1}\right)(38 \mathrm{yr})\right]\right) /\left(0.0225 \mathrm{yr}^{-1}\right) \\
&= 0.034 \mathrm{mrem} \mathrm{yr}^{-1}
\end{aligned}
$$

L Individual Inhalation Dose:

$$
\begin{aligned}
& D_{i}^{\mathrm{inh}}\left[\frac{\mathrm{mrem}}{\mathrm{yr}}\right]=\chi_{i}\left[\frac{\mu \mathrm{Ci}}{\mathrm{m}^{3}}\right] \cdot \mathrm{BR}\left[\frac{\mathrm{m}^{3}}{\mathrm{yr}}\right] \cdot \mathrm{DF}_{\mathrm{i}}^{\mathrm{inh}}\left[\frac{\mathrm{mrem}}{\mu \mathrm{Ci}}\right] \\
& =\left(1.9 \times 10^{-10} \mathrm{mCi} \mathrm{m}^{3}\right)\left(8000 \mathrm{~m}^{3} \mathrm{yr}^{-1}\right)\left(32 \mathrm{mrem} \mathrm{mCi}^{-1}\right) \\
& =4.9 \times 10^{-5} \mathrm{mrem} \mathrm{yr}^{-1}
\end{aligned}
$$

M Individual Vegetable Consumption Dose:

$$
\begin{aligned}
& D_{i}^{\text {veg }}\left[\frac{\text { mrem }}{y r}\right]=\left\{C_{i}^{v} U^{v} f_{v}+C_{i}^{d} U^{l} f_{l}\right\}\left[\frac{\mu C i}{y r}\right] \cdot D F_{i}^{\text {ing }}\left[\frac{\text { mrem }}{\mu C i}\right] \\
& =\left\{\left(5.4 \times 10^{-7} \mathrm{mCi} \mathrm{kg}^{-1}\right)\left(276 \mathrm{~kg} \mathrm{yr}^{-1}\right)(0.76)+\right. \\
& \left.\left(5.4 \times 10-7 \mathrm{mCi} \mathrm{kg}^{-1}\right)\left(43 \mathrm{~kg} \mathrm{yr}^{-1}\right)(1.00)\right\}\left(50 \mathrm{mrem} \mathrm{mCi}^{-1}\right) \\
& =0.0068 \mathrm{mrem} \mathrm{yr}^{-1}
\end{aligned}
$$

P Individual Milk Consumption Dose:

$$
\begin{aligned}
& D_{i}^{m}\left[\frac{m r e m}{y r}\right]=C_{i}^{m}\left[\frac{\mu C i}{L}\right] \cdot U^{m}\left[\frac{L}{y r}\right] \cdot D F_{i}^{i n g}\left[\frac{m r e m}{\mu C i}\right] \\
& =\left\{\left(2.1 \times 10^{-7} \mathrm{mCi} \mathrm{L}^{-1}\right)\left(230 \mathrm{Lyr}^{-1}\right)\left(50 \mathrm{mrem} \mathrm{mCi}^{-1}\right)\right. \\
& =0.0024 \mathrm{mrem} \mathrm{yr}^{-1}
\end{aligned}
$$

Q Individual Meat Consumption Dose:

$$
\begin{aligned}
& D_{i}^{m}\left[\frac{m r e m}{y r}\right]=C_{i}^{m}\left[\frac{\mu C i}{k g}\right] \cdot U^{m}\left[\frac{\mathrm{kg}}{\frac{y r}{r}}\right] \cdot D_{i}^{i n g}\left[\frac{m r e m}{\mu C i}\right] \\
& =\left(\left(4.0 \times 10^{-8} \mathrm{mCi} \mathrm{kg}^{-1}\right)\left(81 \mathrm{~kg} \mathrm{yr}^{-1}\right)\left(50 \mathrm{mrem} \mathrm{mCi}^{-1}\right)\right. \\
& =0.00016 \mathrm{mrem} \mathrm{yr}^{-1}
\end{aligned}
$$




\section{Bench Marking Run}

\begin{tabular}{|c|c|c|c|}
\hline \multicolumn{3}{|c|}{ EXPOSURE PARAMETERS } & \\
\hline Relative Concentration (X/Q): & 7.4E-09 & $(\mathrm{sec} / \mathrm{m} 3)$ & \\
\hline Decayed X/Q: & 7.1E-09 & $(\mathrm{sec} / \mathrm{m} 3)$ & \\
\hline Depleted X/Q: & $6.1 E-09$ & $(\mathrm{sec} / \mathrm{m} 3)$ & \\
\hline Relative Deposition (D/Q): & $3.3 E-11$ & $(1 / \mathrm{m} 2)$ & \\
\hline Distance to Receptor: & 1000 & $(m)$ & \\
\hline nption (AVG, MAX, value): & Max & 276 & $(\mathrm{~kg} / \mathrm{y}$ \\
\hline iption (AVG, MAX, value): & Max & 43 & $(\mathrm{~kg} / \mathrm{yr}$ \\
\hline ption (AVG, MAX, value): & Max & 230 & $(L / y r)$ \\
\hline mption (AVG, MAX, value): & Max & 81 & $(\mathrm{~kg} / \mathrm{yr}$ \\
\hline
\end{tabular}

Origin of Milk (Cow or Goat):

Deposition Buildup Time:

Breathing Rate:

Elemental lodine Fraction:

Absolute Humidity:

Tritium Plant-to-Air Ratio:

Cow

Shielding Factor:

$\begin{array}{cl}38 & (\mathrm{yr}) \\ 8,000 & (\mathrm{~m} 3 / \mathrm{yr}) \\ 1.00 & \\ 0.01125 & (\mathrm{~kg} / \mathrm{m} 3) \\ 0.54 & \end{array}$

Fraction of Year C-14 Released:

0.70

Retained Fraction (iodines):

1.00

1.00

Retained Fraction (particulates):

0.20

Weathering Rate Constant:

Crop Exposure Time:

18.1

$(1 / y r)$

$0.192 \quad(y r)$

Pasture Grass Exposure Time:

Pasture Grass Productivity:

Produce Productivity:

Surface Soil Density $(15 \mathrm{~cm})$ :

Pasture Grass Holdup Time:

0.0822

(yr)

$1.8 \quad(\mathrm{~kg} / \mathrm{m} 2)$

$0.7 \quad(\mathrm{~kg} / \mathrm{m} 2)$

$240 \quad(\mathrm{~kg} / \mathrm{m} 2)$

Stored Feed Holdup Time:

$0.00000 \quad$ (yrs)

$0.24700 \quad$ (yrs)

Leafy Vegetable Holdup Time:

Produce Holdup Time:

$0.00274 \quad$ (yrs)

$0.16400 \quad$ (yrs)

Milk Cattle Feed Consumption (52):

Beef Cattle Feed Consumption:

Feed-Milk-Man Transport Time:

Fraction of Year on Pasture (beef):

52

(kg/day)

36 (kg/day)

$0.00822(y r)$

1.00

Fraction of Year on Pasture (milk): 1.00

Fraction Intake from Pasture (beef):

0.75

1.00 suggested

Fraction Intake from Pasture (milk):

Slaughter to Consumption Time:

Fraction of Produce from Garden:

0.56

0.56 suggested

0.0164

(yr)

Fraction of Leafy Vegs from Garden: $\quad 1.00$ 


\section{SOURCE TERM ENTRY}

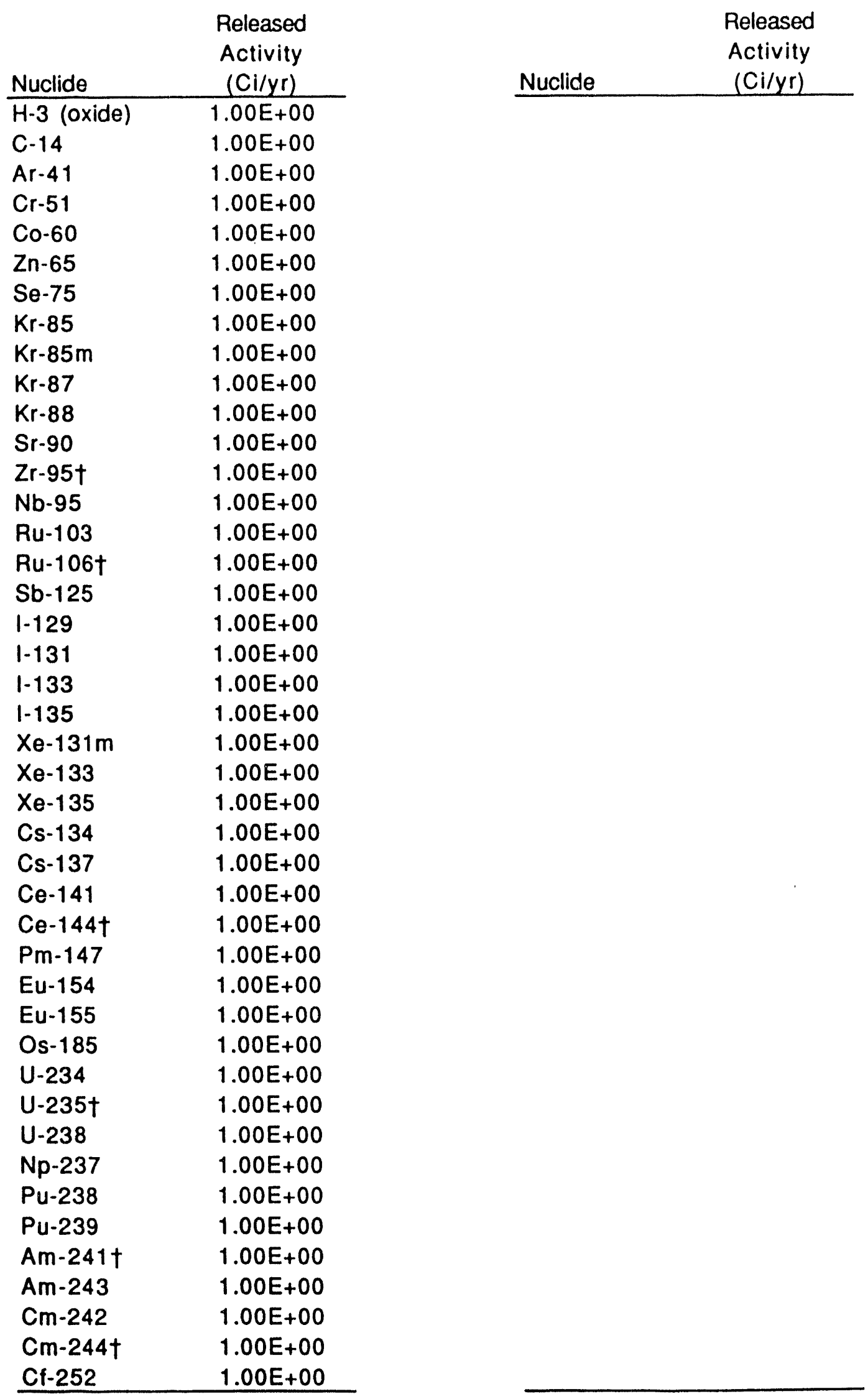

tDenotes preferred isotope when isotopic breakdown in not available. 


\section{Atmospheric Transport and External Dose Factors}

\begin{tabular}{|c|c|c|c|c|c|c|}
\hline Nuclide & $\begin{array}{c}\text { Deposition } \\
\text { Rate } \\
\text { (uCi/m2 yr) }\end{array}$ & $\begin{array}{c}\text { Atmospheric } \\
\text { Concentration } \\
(u \mathrm{Ci} / \mathrm{m} 3)\end{array}$ & $\begin{array}{l}\text { Plume-Shine } \\
\text { EDE DFs } \\
\text { (mrem_m3) } \\
\text { (yr uCi) }\end{array}$ & $\begin{array}{l}\text { Plume-Shine } \\
\text { Skin DFs } \\
\text { (mrem m3) } \\
\text { (yr uCi) }\end{array}$ & $\begin{array}{l}\text { Ground-Shine } \\
\text { EDE DFs } \\
\text { (mrem m2) } \\
\text { (yr uCi) }\end{array}$ & $\begin{array}{l}\text { Ground-Shine } \\
\text { Skin DFs } \\
\frac{\text { (mrem m2) }}{(y r \text { uCi })}\end{array}$ \\
\hline $\mathrm{H}-3$ & & $2.3 E-10$ & & & & \\
\hline$C-14$ & & $2.3 E-10$ & & & & \\
\hline Ar -41 & ; & $2.3 E-10$ & $6.63 E+03$ & $1.22 E+04$ & & \\
\hline $\mathrm{Cr}-51$ & $3.3 E-05$ & $1.9 E-10$ & & & $3.41 E+00$ & $4.53 E+00$ \\
\hline Co- 60 & 3.3E-05 & $1.9 E-10$ & & & 2.27E+02 & $3.10 E+02$ \\
\hline $\mathrm{Zn}-65$ & 3.3E-05 & $1.9 E-10$ & & & $5.48 E+01$ & $7.45 E+01$ \\
\hline Se-75 & $3.3 E-05$ & $1.9 E-10$ & & & $4.32 E+01$ & $5.65 E+01$ \\
\hline$K r-85$ & & 2.3E-10 & $1.12 E+01$ & $1.58 E+03$ & & \\
\hline$K r-85 m$ & & 2.3E-10 & $8.17 E+02$ & $2.62 E+03$ & & \\
\hline Kr-87 & & $2.3 E-10$ & $4.47 E+03$ & $1.65 E+04$ & & \\
\hline$K r-88^{*}$ & : & 2.3E-10 & $1.49 E+04$ & $3.92 E+04$ & & \\
\hline Sr-90 & $3.3 E-05$ & $1.9 E-10$ & & & $0.00 E+00$ & $1.27 E+03$ \\
\hline $\mathrm{Zr}-95^{*}$ & 3.3E-05 & $1.9 \mathrm{E}-10$ & & & $1.52 E+02$ & $2.10 E+02$ \\
\hline Nb-95 & 3.3E-05 & $1.9 E-10$ & & & $7.76 E+01$ & $1.10 E+02$ \\
\hline$R u-103^{*}$ & 3.3E-05 & $1.9 E-10$ & & & $5.01 E+01$ & $7.19 E+01$ \\
\hline$R u-106^{*}$ & 3.3E-05 & $1.9 E-10$ & & & $2.10 E+01$ & $1.66 E+03$ \\
\hline$S b-125$ & 3.3E-05 & $1.9 E-10$ & & & 4.43E+01 & $6.71 E+01$ \\
\hline $1-129$ & $3.3 E-05$ & $1.9 E-10$ & & & $2.20 E+00$ & $5.30 E+00$ \\
\hline $1-131^{*}$ & $3.3 E-05$ & $1.9 E-10$ & & & $4.04 E+01$ & $7.56 \mathrm{E}+01$ \\
\hline $1-133^{*}$ & $3.3 E-05$ & $1.9 E-10$ & & & $6.67 E+01$ & $5.39 E+02$ \\
\hline $1-135$ & $3.3 E-05$ & $1.9 E-10$ & & 4 & $1.45 E+02$ & $5.62 E+02$ \\
\hline Xe-131m & & 2.3E-10 & $4.29 E+01$ & $5.61 E+02$ & & \\
\hline$x e-133$ & & 2.3E-10 & $1.76 \mathrm{E}+02$ & $5.81 E+02$ & & \\
\hline Xe-135 & . & 2.3E-10 & $1.25 E+03$ & $3.64 E+03$ & & \\
\hline Cs-134 & $3.3 E-05$ & $1.9 E-10$ & & & $1.58 E+02$ & $2.50 E+02$ \\
\hline Cs-137" & 3.3E-05 & $1.9 E-10$ & & & $5.78 E+01$ & $2.09 E+02$ \\
\hline $\mathrm{Ce}-141$ & 3.3E-05 & $1.9 E-10$ & & & $8.78 E+00$ & $1.60 E+01$ \\
\hline $\mathrm{Ce}-144^{*}$ & 3.3E-05 & $1.9 E-10$ & & & $5.10 E+00$ & $1.47 E+03$ \\
\hline Pm-147 & 3.3E-05 & $1.9 E-10$ & & & 4.10E-04 & 4.96E-04 \\
\hline Eu-154 & 3.3E-05 & $1.9 E-10$ & & & $1.21 E+02$ & $3.12 E+02$ \\
\hline Eu-155 & 3.3E-05 & $1.9 E-10$ & & & $7.15 E+00$ & $9.39 E+00$ \\
\hline Os-185 & 3.3E-05 & $1.9 E-10$ & & & $7.29 E+01$ & $1.07 E+02$ \\
\hline U-234 & 3.3E-05 & $1.9 E-10$ & & & 8.07E-02 & $6.40 E-01$ \\
\hline U-235 & 3.3E-05 & $1.9 E-10$ & & & $1.71 E+01$ & $2.30 E+01$ \\
\hline U-238 & $3.3 E-05$ & $1.9 E-10$ & & & $6.46 \mathrm{E}-02$ & 5.30E-01 \\
\hline Np-237 & $3.3 E-05$ & $1.9 E-10$ & & & $3.24 E+00$ & $7.50 E+00$ \\
\hline$P u-238$ & 3.3E-05 & $1.9 E-10$ & & & 8.58E-02 & 7.20E-01 \\
\hline $\mathrm{Pu}-239$ & 3.3E-05 & $1.9 E-10$ & & & 3.78E-02 & $2.80 E-01$ \\
\hline Am-241 & 3.3E-05 & $1.9 E-10$ & & & $2.99 E+00$ & $6.40 E+00$ \\
\hline Am-243 & $3.3 E-05$ & $1.9 E-10$ & & & $6.61 E+00$ & $1.06 E+01$ \\
\hline Cm-242* & 3.3E-05 & $1.9 E-10$ & & & 1.79E-01 & $1.45 E+00$ \\
\hline $\mathrm{Cm}-244$ & 3.3E-05 & $1.9 E-10$ & & & 8.29E-02 & $6.60 \mathrm{E}-01$ \\
\hline Cf-252 & 3.3E-05 & $1.9 E-10$ & & & $6.34 E-02$ & 4.70E-01 \\
\hline
\end{tabular}

Nuclides in BOLD have modified deposition and atm. concentration models.

"These dose factors include contributions from daughter radiations (as per SRL-ETS-910233). 
CONVERSION FACTORS

\begin{tabular}{|c|c|c|c|c|c|c|}
\hline Nuclide & $\begin{array}{c}\text { Decay } \\
\text { Constant } \\
(1 / y r)\end{array}$ & $\begin{array}{c}\text { Inhalation EDE } \\
\text { Dose Factor } \\
\text { (rem/uCi) }\end{array}$ & $\begin{array}{c}\text { Ingestion EDE } \\
\text { Dose Factor } \\
\text { (rem/uCi) }\end{array}$ & $\begin{array}{c}\text { Vegetable } \\
\text { to Soil } \\
\text { Ratio }\end{array}$ & $\begin{array}{l}\text { Cow Milk } \\
\text { Transfor } \\
\text { (d/L) }\end{array}$ & $\begin{array}{c}\text { Intake To Meat } \\
\text { Transfer } \\
\text { (d/kg) }\end{array}$ \\
\hline $\mathrm{H}-3$ & $5.61 E-02$ & $9.5 \mathrm{E}-05$ & $6.3 E-05$ & $4.8 E+00$ & $1.0 \mathrm{E}-02$ & $1.2 \mathrm{E}-02$ \\
\hline$C-14$ & 1.21E-04 & $2.4 E-05$ & $2.1 E-03$ & $5.5 E+00$ & $1.2 E-02$ & $3.1 E-02$ \\
\hline Ar-41 & $3.31 E+03$ & & & & & \\
\hline $\mathrm{Cr}-51$ & $9.13 E+00$ & $2.6 E-04$ & $1.3 E-04$ & $2.5 E-04$ & $2.2 E-03$ & $2.4 \mathrm{E}-03$ \\
\hline Co- 60 & $1.32 E-01$ & $1.5 E-01$ & 2.6E-02 & $9.4 E-03$ & 1.0E-03 & 1.3E-02 \\
\hline $\mathrm{Zn}-65$ & $1.03 E+00$ & $1.8 E-02$ & $1.4 E-02$ & 4.0E-01 & $3.9 E-02$ & $3.0 \mathrm{E}-02$ \\
\hline $\mathrm{Se}-75$ & $2.11 E+00$ & 8.2E-03 & $8.8 E-03$ & $1.3 E+00$ & $4.5 \mathrm{E}-02$ & $1.5 \mathrm{E}-02$ \\
\hline $\mathrm{Kr}-85$ & $6.46 \mathrm{E}-02$ & & & & & \\
\hline $\mathrm{Kr}-85 \mathrm{~m}$ & 1.36E+03 & & & & & \\
\hline$K r-87$ & $4.76 E+03$ & & & & & \\
\hline $\mathrm{Kr}-88$ & $2.14 E+03$ & & & & & \\
\hline Sr -90 & $2.38 E-02^{\checkmark}$ & $1.3 E+00$ & $1.3 E-01$ & $1.7 E-02$ & $8.0 E-04$ & $6.0 E-04$ \\
\hline$Z r-95$ & $3.85 E+00$ & $1.9 E-02$ & $3.4 E-03$ & $1.7 E-04$ & $5.0 E-06$ & $3.4 \mathrm{E}-02$ \\
\hline $\mathrm{Nb}-95$ & $7.22 E+00$ & 4.5E-03 & $2.2 E-03$ & $9.4 E-03$ & $2.5 E-03$ & 2.8E-01 \\
\hline$R u-103$ & $6.37 E+00$ & 7.8E-03 & 2.7E-03 & 5.0E-02 & $1.0 E-06$ & 4.0E-01 \\
\hline$R u-106$ & $6.84 E-01$ & $4.4 E-01$ & 2.1E-02 & $5.0 E-02$ & $1.0 \mathrm{E}-06$ & 4.0E-01 \\
\hline Sb-125 & 2.50E-01 & $9.8 E-03$ & 2.6E-03 & & & \\
\hline $1-129$ & 4.35E-08 & 1.8E-01 & 2.8E-01 & $2.0 E-02$ & $6.0 \mathrm{E}-03$ & 2.9E-03 \\
\hline $\mid-131$ & $3.14 E+01$ & $3.2 E-02$ & 5.3E-02 & $2.0 E-02$ & $6.0 E-03$ & $2.9 E-03$ \\
\hline $1-133$ & $2.92 E+02$ & $5.4 E-03$ & $1.0 E-02$ & 2.0E-02 & $6.0 \mathrm{E}-03$ & $2.9 E-03$ \\
\hline 1.135 & $9.21 E+02$ & $1.1 \mathrm{E}-03$ & $2.0 E-03$ & $2.0 E-02$ & $6.0 \mathrm{E}-03$ & $2.9 \mathrm{E}-03$ \\
\hline$x e-131 m$ & $2.14 E+01$ & & & & & \\
\hline$x e-133$ & $4.82 E+01$ & & & & & \\
\hline$X_{\theta}-135$ & $6.68 E+02$ & & & & & \\
\hline Cs-134 & 3.37E-01 & 4.7E-02 & $7.4 \mathrm{E}-02$ & $1.0 \mathrm{E}-02$ & 1.2E-02 & 4.0E-03 \\
\hline Cs-137 & 2.25E-02 & $3.2 E-02$ & $5.0 \mathrm{E}-02$ & $1.0 \mathrm{E}-02$ & $1.2 E-02$ & 4.0E-03 \\
\hline $\mathrm{Ce}-141$ & $7.79 E+00$ & 8.5E-03 & 2.6E-03 & $2.5 E-03$ & $6.0 E-04$ & $1.2 E-03$ \\
\hline $\mathrm{Ce}-144$ & 8.92E-01 & 3.5E-01 & 2.0E-02 & 2.5E-03 & $6.0 E-04$ & $1.2 E-03$ \\
\hline Pm-147 & 2.64E-01 & 3.4E-02 & $9.5 E-04$ & & & \\
\hline Eu-154 & 7.88E-02 & 2.6E-01 & $9.1 E-03$ & & & \\
\hline Eu-155 & $1.40 E-01$ & $3.9 E-02$ & 1.3E-03 & & & \\
\hline Os-185 & $2.70 E+00$ & $1.0 \mathrm{E}-02$ & 2.1E-03 & $5.0 \mathrm{E}-02$ & $5.0 E-03$ & $4.0 E-01$ \\
\hline U-234 & 2.84E-06 & $1.3 E+02$ & 2.6E-01 & $2.5 E-03$ & $5.0 E-04$ & $3.4 E-04$ \\
\hline U-235 & $9.81 E-10$ & $1.2 E+02$ & $2.5 E-01$ & $2.5 E-03$ & 5.0E-04 & $3.4 E-04$ \\
\hline U-238 & 1.55E-10 & $1.2 E+02$ & 2.3E-01 & $2.5 E-03$ & $5.0 E-04$ & $3.4 E-04$ \\
\hline Np-237 & 3.25E-07 & $4.9 E+02$ & $3.9 E+00$ & $2.5 E-03$ & $5.0 E-06$ & 2.0E-04 \\
\hline Pu-238 & $7.88 E-03$ & $4.6 E+02$ & $3.8 E+00$ & $2.5 E-04$ & $2.0 E-06$ & $1.4 E-05$ \\
\hline Pu-239 & 2.84E-05 & $5.1 E+02$ & $4.3 E+00$ & $2.5 E-04$ & $2.0 E-06$ & $1.4 E-05$ \\
\hline Am-241 & $1.60 \mathrm{E}-03$ & $5.2 E+02$ & $4.5 E+00$ & $2.5 E-04$ & $5.0 \mathrm{E}-06$ & $2.0 E-04$ \\
\hline$A m-\angle 43$ & 9.39E-05 & $5.2 E+02$ & $4.5 E+00$ & $2.5 E-04$ & $5.0 \mathrm{E}-06$ & $2.0 E-04$ \\
\hline $\mathrm{Cm}-242$ & $1.55 E+00$ & $1.7 E+01$ & $1.1 E-01$ & 2.5E-03 & 5.0E-06 & $2.0 E-04$ \\
\hline $\mathrm{Cm}-244$ & $3.88 \mathrm{E}-02$ & $2.7 E+02$ & $2.3 E+00$ & $2.5 E-03$ & $5.0 \mathrm{E}-06$ & $2.0 E-04$ \\
\hline$C \uparrow-252$ & 2.62E-01 & $1.3 E+02$ & $9.4 E-01$ & $2.5 E-03$ & 5.0 E-06 & 2.0E-04 \\
\hline
\end{tabular}


FOOD AND FODDER CONCENTRATIONS

\begin{tabular}{|c|c|c|c|c|c|c|}
\hline Nuclide & $\begin{array}{c}\text { Other } \\
\text { Vegetables } \\
(u \mathrm{Cl} / \mathrm{kg})\end{array}$ & $\begin{array}{c}\text { Leafy } \\
\text { Vegetables } \\
(u \mathrm{Cl} / \mathrm{kg})\end{array}$ & $\begin{array}{c}\text { Milk } \\
(u \mathrm{Ci} / L) \\
\end{array}$ & $\begin{array}{c}\text { Meat } \\
(\mathrm{uCl} / \mathrm{kg})\end{array}$ & $\begin{array}{l}\text { Pasture } \\
\text { Grass } \\
\text { (uCi/kg) } \\
\end{array}$ & $\begin{array}{l}\text { Stored } \\
\text { Feed } \\
(\mathrm{uCl} / \mathrm{kg}) \\
\end{array}$ \\
\hline $\mathrm{H}-3$ & 8.4E-09 & 8.4E-09 & 4.4E-09 & $3.6 E-09$ & $8.4 E-09$ & $8.4 E-09$ \\
\hline $\mathrm{C} \cdot 14^{*}$ & $1.6 \mathrm{E}-07$ & $1.6 \mathrm{E}-07$ & $1.0 E-07$ & $1.8 E-07$ & $1.6 \mathrm{E}-07$ & $1.6 \mathrm{E}-07$ \\
\hline $\operatorname{Ar}-41$ & . & & & & 1: & 1/1:. \\
\hline Cr-51 & 7.7E-08 & $3.4 E-07$ & 8.8E-09 & $7.4 E-09$ & $1.2 E-07$ & $3.6 \mathrm{E}-08$ \\
\hline Co-60 & 5.0E-07 & 5.1E-07 & $1.6 E-08$ & $1.2 E-07$ & 1.7E-07 & $4.9 E-07$ \\
\hline $\mathrm{Zn}-65$ & 4.5E-07 & 5.3E-07 & $6.0 E-07$ & 2.7E-07 & 2.1E-07 & 4.1E-07 \\
\hline Se-75 & $3.8 E-07$ & $5.4 \mathrm{E}-07$ & $6.2 E-07$ & $1.3 E-07$ & $2.3 E-07$ & $3.2 E-07$ \\
\hline \multicolumn{7}{|l|}{$\mathrm{Kr}-85$} \\
\hline \multicolumn{7}{|l|}{$\mathrm{Kr}-85 \mathrm{~m}$} \\
\hline \multicolumn{7}{|l|}{ Kr-87 } \\
\hline \multicolumn{7}{|l|}{$\mathrm{Kr}-88$} \\
\hline Sr-90 & 5.6E-07 & 5.6E-07 & $1.5 E-08$ & $6.5 E-09$ & 2.2E-07 & 5.6E-07 \\
\hline$Z r-95$ & 2.3E-07 & $4.2 E-07$ & $3.8 E-11$ & 1.7E-07 & $1.4 E-07$ & $1.6 \mathrm{E}-07$ \\
\hline $\mathrm{Nb}-95$ & 1.1E-07 & $3.6 \mathrm{E}-07$ & $1.2 E-08$ & 9.9E-07 & 1.3E-07 & $6.2 E-08$ \\
\hline$R u-103$ & 1.3E-07 & 3.8E-07 & 5.3E-12 & $1.5 E-06$ & 1.3E-07 & $7.9 E-08$ \\
\hline$R u-106$ & 4.5E-07 & 5.0E-07 & $1.4 E-11$ & $3.2 E-06$ & 1.6E-07 & $4.2 E-07$ \\
\hline Sb-125 & $4.8 E-07$ & $5.0 E-07$ & $0.0 E+00$ & $0.0 E+00$ & $1.6 E-07$ & 4.7E-07 \\
\hline 1.129 & 2.6E-06 & 2.6E-06 & 5.2E-07 & $1.4 E-07$ & 8.9E-07 & $2.6 \mathrm{E}-06$ \\
\hline 1131 & 5.5E-09 & 8.7E-07 & 4.9E-08 & $1.7 E-08$ & 3.6E-07 & 4.1E-10 \\
\hline 1.133 & $2.4 E-28$ & $6.8 E-08$ & $9.4 E-10$ & $3.8 E-11$ & 5.9E-08 & 7.2E-39 \\
\hline $1-135$ & $1.3 E-73$ & $4.0 E-09$ & $1.7 E-12$ & $4.2 E-16$ & $1.9 E-08$ & $8.0 \mathrm{E}-107$ \\
\hline \multicolumn{7}{|l|}{$X e-131 m$} \\
\hline \multicolumn{7}{|l|}{$X_{\theta}-133$} \\
\hline \multicolumn{7}{|l|}{$X e-135$} \\
\hline Cs-134 & 4.7E-07 & 5.0E-07 & 1.8E-07 & $3.4 E-08$ & $1.6 \mathrm{E}-07$ & 4.6E-07 \\
\hline Cs-137 & 5.4E-07 & 5.4E-07 & 2.1E-07 & $4.0 E-08$ & $1.9 E-07$ & 5.4E-07 \\
\hline $\mathrm{Ce}-141$ & $1.0 \mathrm{E}-07$ & $3.5 E-07$ & 2.7E-09 & 4.1E-09 & 1.2E-07 & $5.3 E-08$ \\
\hline $\mathrm{Ce}-144$ & 4.2E-07 & 4.8E-07 & 7.9E-09 & $9.0 E-09$ & $1.5 E-07$ & $3.9 E-07$ \\
\hline Pm-147 & 4.8E-07 & $5.0 E-07$ & $0.0 E+00$ & $0.0 E+00$ & 1.6E-07 & 4.7E-07 \\
\hline Eu-154 & 5.0E-07 & $5.0 E-07$ & $0.0 E+00$ & $0.0 E+00$ & $1.6 \mathrm{E}-07$ & 4.9E-07 \\
\hline Eu-155 & 4.9E-07 & $5.0 E-07$ & $0.0 E+00$ & $0.0 E+00$ & 1.6E-07 & $4.8 E-07$ \\
\hline Os-185 & 2.9E-07 & 4.4E-07 & 4.7E-08 & 2.3E-06 & $1.5 E-07$ & 2.3E-07 \\
\hline U-234 & 5.2E-07 & 5.2E-07 & $8.4 E-09$ & 3.1E-09 & 1.7E-07 & 5.2E-07 \\
\hline U-235 & 5.2E-07 & 5.2E-07 & $8.4 E-09$ & 3.1E-09 & $1.7 E-07$ & 5.2E-07 \\
\hline U-238 & 5.2E-07 & 5.2E-07 & 8.4E-09 & 3.1E-09 & 1.7E-07 & $5.2 E-07$ \\
\hline Np-237 & 5.2E-07 & 5.2E-07 & $8.4 E-11$ & 1.8E-09 & 1.7E-07 & 5.2E-07 \\
\hline Pu-238 & 5.1E-07 & 5.1E-07 & $3.2 E-11$ & $1.2 E-10$ & 1.6E-07 & 5.0E-07 \\
\hline Pu-239 & 5.1E-07 & 5.1E-07 & $3.2 E-11$ & $1.2 E-10$ & 1.6E-07 & 5.1E-07 \\
\hline Am-241 & 5.1E-07 & 5.1E-07 & 8.1E-11 & $1.8 E-09$ & 1.6E-07 & 5.1E-07 \\
\hline Am-243 & 5.1E-07 & 5.1E-07 & $8.1 E-11$ & $1.8 E-09$ & 1.6E-07 & 5.1E-07 \\
\hline $\mathrm{Cm}-242$ & $3.6 E-07$ & 4.7E-07 & $5.8 E-11$ & 1.3E-09 & $1.5 E-07$ & 3.2E-07 \\
\hline Cm-244 & 5.1E-07 & 5.1E-07 & $8.2 E-11$ & 1.8E-09 & 1.6E-07 & 5.1E-07 \\
\hline Cf-252 & $4.8 E-07$ & $5.0 \mathrm{E}-07$ & $7.6 \mathrm{E}-11$ & 1.7E-09 & 1.6E-07 & 4.7E-07 \\
\hline
\end{tabular}

concentrations determined using element specific model. 
Dose to Maximum Individual Living at the SRS Boundary 50-year CEDE from a 1-Year Intake (mrem)

\begin{tabular}{|c|c|c|c|c|c|c|}
\hline Nuclide & $\begin{array}{c}\text { Shine Doset } \\
\text { (mrem) }\end{array}$ & $\begin{array}{c}\text { Inhalation } \\
\text { (mrem) }\end{array}$ & $\begin{array}{c}\text { Vegetables } \\
\text { (mrem) }\end{array}$ & $\begin{array}{l}\text { Cow Milk } \\
\text { (mrem) }\end{array}$ & $\begin{array}{c}\text { Meat } \\
\text { (mrem) }\end{array}$ & $\begin{array}{l}\text { TOTAL } \\
\text { (mrem) }\end{array}$ \\
\hline $\mathrm{H}-3$ & & $1.8 \mathrm{E}-07$ & 1.3E-07 & $6.4 E-08$ & $1.9 E-08$ & $3.9 E-07$ \\
\hline C-14 & & & 8.6E-05 & $4.9 E-05$ & $3.1 E-05$ & 1.6E-04 \\
\hline Ar -41 & 1.1E-06 & & & & & 1.1E-06 \\
\hline Cr-51 & $8.6 E-06$ & $4.0 \mathrm{E}-07$ & 4.0E-06 & $2.6 \mathrm{E}-07$ & $7.8 E-08$ & 1.3E-05 \\
\hline Co-60 & 3.9E-02 & 2.3E-04 & 3.3E-03 & $9.7 E-05$ & 2.4E-04 & 4.3E-02 \\
\hline $2 n-65$ & $1.2 E-03$ & $2.8 E-05$ & $1.6 E-03$ & $1.9 E-03$ & 3.1E-04 & 5.1E-03 \\
\hline Se-75 & 4.7E-04 & $1.3 E-05$ & $9.1 E-04$ & $1.3 E-03$ & $9.5 E-05$ & 2.8E-03 \\
\hline $\mathrm{Kr}-85$ & $1.8 E-09$ & & & & & 1.8E-09 \\
\hline $\mathrm{Kr}-85 \mathrm{~m}$ & 1.3E-07 & & & & & 1.3E-07 \\
\hline $\mathrm{Kr}-87$ & 7.1E-07 & & & & & 7.1E-07 \\
\hline $\mathrm{Kr}-88$ & 2.4E-06 & & & & & $2.4 E-06$ \\
\hline Sr-90 & - & $2.0 E-03$ & $1.8 E-02$ & 4.6E-04 & $6.9 E-05$ & 2.1E-02 \\
\hline$Z r-95$ & $9.1 E-04$ & $2.9 E-05$ & 2.2E-04 & $3.0 E-08$ & 4.6E-05 & $1.2 E-03$ \\
\hline $\mathrm{Nb}-95$ & 2.5E-04 & 7.0E-06 & 8.7E-05 & 6.1E-06 & $1.8 E-04$ & 5.2E-04 \\
\hline$R u-103$ & 1.8E-04 & 1.2E-05 & $1.2 E-04$ & 3.3E-09 & 3.3E-04 & 6.5E-04 \\
\hline$R u-106$ & 7.1E-04 & $6.8 E-04$ & $2.4 E-03$ & $6.9 E-08$ & 5.5E-03 & 9.3E-03 \\
\hline Sb-125 & 4.1E-03 & $1.5 E-05$ & $3.2 E-04$ & $0.0 E+00$ & $0.0 E+00$ & $4.4 E-03$ \\
\hline 1.129 & 1.9E-03 & $2.8 E-04$ & $1.9 E-01$ & 3.3E-02 & $3.1 E-03$ & 2.2E-01 \\
\hline $\mid-131$ & 3.0E-05 & 4.9E-05 & 2.1E-03 & 6.0E-04 & 7.3E-05 & 2.8E-03 \\
\hline $1-133$ & 5.3E-06 & 8.3E-06 & 2.9E-05 & $2.2 E-06$ & 3.1E-08 & 4.5E-05 \\
\hline $1-135$ & 3.6E-06 & $1.7 E-06$ & $3.4 \mathrm{E}-07$ & $8.0 E-10$ & $6.8 E-14$ & 5.6E-06 \\
\hline$x e-131 m$ & 7.0E-09 & & & & & 7.0E-09 \\
\hline $\mathrm{Xe-133}$ & 2.9E-08 & & & & & 2.9E-08 \\
\hline$X e-135$ & 2.0E-07 & & & & & 2.0E-07 \\
\hline Cs-134 & 1.1E-02 & 7.3E-05 & $8.9 E-03$ & $3.1 E-03$ & 2.0E-04 & 2.3E-02 \\
\hline Cs-137 & 3.4E-02 & $5.0 E-05$ & $6.8 E-03$ & 2.5E-03 & 1.6E-04 & 4.4E-02 \\
\hline$C_{\theta-141}$ & $2.6 E-05$ & $1.3 E-05$ & 9.5E-05 & $1.6 \mathrm{E}-06$ & 8.6E-07 & $1.4 E-04$ \\
\hline $\mathrm{Ce}-144$ & 1.3E-04 & $5.4 E-04$ & 2.2E-03 & 3.7E-05 & 1.5E-05 & $2.9 E-03$ \\
\hline Pm-147 & 3.6E-08 & 5.3E-05 & $1.2 E-04$ & $0.0 E+00$ & $0.0 E+00$ & 1.7E-04 \\
\hline Eu-154 & $3.4 E-02$ & $4.0 E-04$ & 1.1E-03 & $0.0 E+00$ & $0.0 E+00$ & 3.5E-02 \\
\hline Eu-155 & $1.2 E-03$ & $6.0 E-05$ & $1.6 E-04$ & $0.0 E+00$ & $0.0 E+00$ & $1.4 \mathrm{E}-03$ \\
\hline Os-185 & $6.2 E-04$ & $1.5 E-05$ & 1.7E-04 & $2.3 E-05$ & $3.9 E-04$ & $1.2 E-03$ \\
\hline U-234 & 7.1E-05 & $2.0 \mathrm{E}-01$ & $3.4 E-02$ & $5.0 E-04$ & 6.6E-05 & 2.4E-01 \\
\hline$U-235$ & 1.5E-02 & $1.9 E-01$ & 3.3E-02 & 4.8E-04 & $6.4 E-05$ & 2.3E-01 \\
\hline$U-238$ & 5.7E-05 & $1.9 E-01$ & 3.0E-02 & 4.4E-04 & $5.9 E-05$ & 2.2E-01 \\
\hline Np-237 & 2.8E-03 & 7.6E-01 & 5.1E-01 & $7.5 E-05$ & $5.8 E-04$ & $1.3 E+00$ \\
\hline Pu-238 & $6.5 E-05$ & 7.1E-01 & 4.9E-01 & $2.8 E-05$ & $3.8 E-05$ & $1.2 E+00$ \\
\hline Pu-239 & 3.3E-05 & 7.9E-01 & $5.5 \mathrm{E}-01$ & 3.2E-05 & 4.3E-05 & $1.3 E+00$ \\
\hline Am-241 & $2.5 E-03$ & $8.0 E-01$ & $5.8 E-01$ & 8.4E-05 & $6.4 E-04$ & $1.4 E+00$ \\
\hline Am-243 & 5.8E-03 & 8.0E-01 & 5.8E-01 & 8.4E-05 & $6.4 E-04$ & $1.4 E+00$ \\
\hline $\mathrm{Cm}-242$ & 2.7E-06 & $2.6 E-02$ & $1.1 \mathrm{E}-02$ & $1.5 \mathrm{E}-06$ & $1.2 E-05$ & 3.7E-02 \\
\hline $\mathrm{Cm}-244$ & $3.8 \mathrm{E}-05$ & 4.2E-01 & 3.0E-01 & 4.3E-05 & 3.3E-04 & 7.1E-01 \\
\hline \multirow[t]{2}{*}{ Cf-252 } & 5.6E-06 & $2.0 E-01$ & 1.1E-01 & 1.6E-05 & 1.3E-04 & $3.2 \mathrm{E}-01$ \\
\hline & 1.6E-01 & $5.1 E+00$ & $3.5 E+00$ & $4.5 \mathrm{E}-02$ & $1.3 E-02$ & $8.8 E+00$ \\
\hline
\end{tabular}

tPlume-shine doses calculated for noble gases only; others in column are ground-shine doses. 
APPENDIX B

Comparison of PC to Mainframe Results Dispersion Factor and Dose Ratios 
Percent Difference from MAXIGASP*

A-Area C-Area Site Center D-Area F-Area

X/Q
Decay X/Q
Depleted X/Q
D/Q
$11 \%$

$\mathrm{H} \cdot 3$

$11 \%$

C. 14

Ar -41

Cr-51

Co-60

$\mathrm{Zn}-65$

$\mathrm{Kr}-85$

$\mathrm{Kr}-85 \mathrm{~m}$

$\mathrm{Kr}-87$

$\mathrm{Kr} \cdot 88$

Sr -90

Zr-95

$\mathrm{Nb}-95$

$\mathrm{Ru}-103$

$\mathrm{Ru}-106$

Sb-125

1.129

1.131

$1-133$

1.135

$x_{\theta}-131 \mathrm{~m}$

$12 \%$

$X_{\theta}-133$

$\mathrm{Xe}-135$

Cs-134

Cs-137

Ce-141

Ce-144

Pm-147

Eu-154

Eu-155

U-234

U-235

U -238

Np-237

$\mathrm{Pu}-238$

Pu-239

Am-241

$12 \%$

$30 \%$

$-12 \%$

$.11 \%$

$.13 \%$

$13 \%$

$12 \%$

$13 \%$

$13 \%$

$16 \%$

$43 \%$

$23 \%$

$-12 \%$

$.13 \%$

$.12 \%$

$-12 \%$

$.12 \%$

$-13 \%$

$.12 \%$

$-11 \%$

$<\cdots$

$<\cdot$.

Am-243

$13 \%$

$11 \%$

$13 \%$

$.11 \%$

$<\cdots$

$-12 \%$

$.13 \%$

$<\cdots$

$12 \%$

( 
Percent Difference from MAXIGASP*

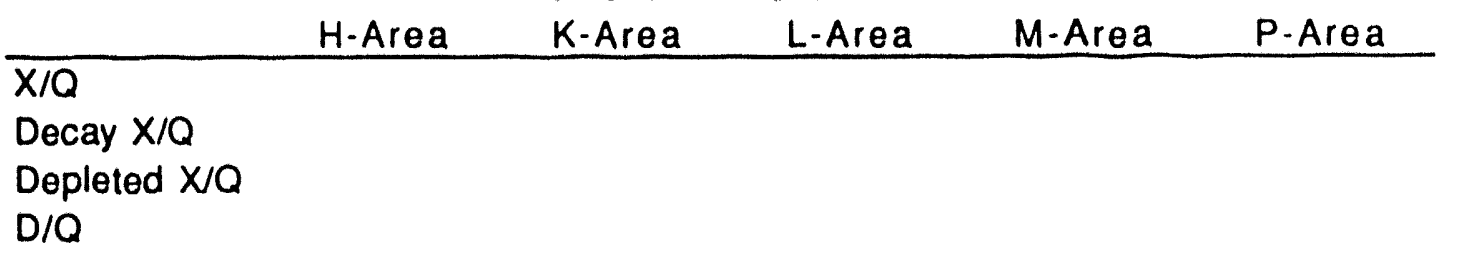

H-3

C. 14

Ar -41

Cr-51

Co-60

$\mathrm{Zn}-65$

$\mathrm{Kr}-85$

$\mathrm{Kr}-85 \mathrm{~m}$

$\mathrm{Kr}-87$

$\mathrm{Kr}-88$

Sr -90

$\mathrm{Zr}-95$

$\mathrm{Nb}-95$

Ru-103

Ru-106

Sb-125

1.129

$1-131$

$1-133$

$1-135$

$\mathrm{Xe}-131 \mathrm{~m}$

$X_{e}-133$

$\mathrm{Xe}-135$

Cs-134

Cs-137

Ce-141

$\mathrm{Ce}-144$

Pm-147

Eu-154

Eu-155

$U-234$

$\mathrm{U}-235$

$U-238$

$\mathrm{Np}-237$

$\mathrm{Pu}-238$

Pu-239

Am-241

Am-243

$\mathrm{Cm}-242$

$\mathrm{Cm}-244$

Cf-252
$13 \%-12 \%$

$14 \%$

$14 \%$

$12 \%$ $<\cdots$

$<\cdots$

$<\cdots$

$<\cdots$

$<\cdots$

$<\cdots$

$<-\cdot$

$<\cdots$

$$
\begin{aligned}
& <\cdots \\
& <\cdots \\
& <\cdots \\
& <\cdots \\
& <\cdots \\
& <\cdots \\
& <\cdots \\
& <\cdots \\
& <\cdots
\end{aligned}
$$

Arrows at the right indicate nuclides routinely released at SRS.

"only values greater than $\pm 10 \%$ are reported. 

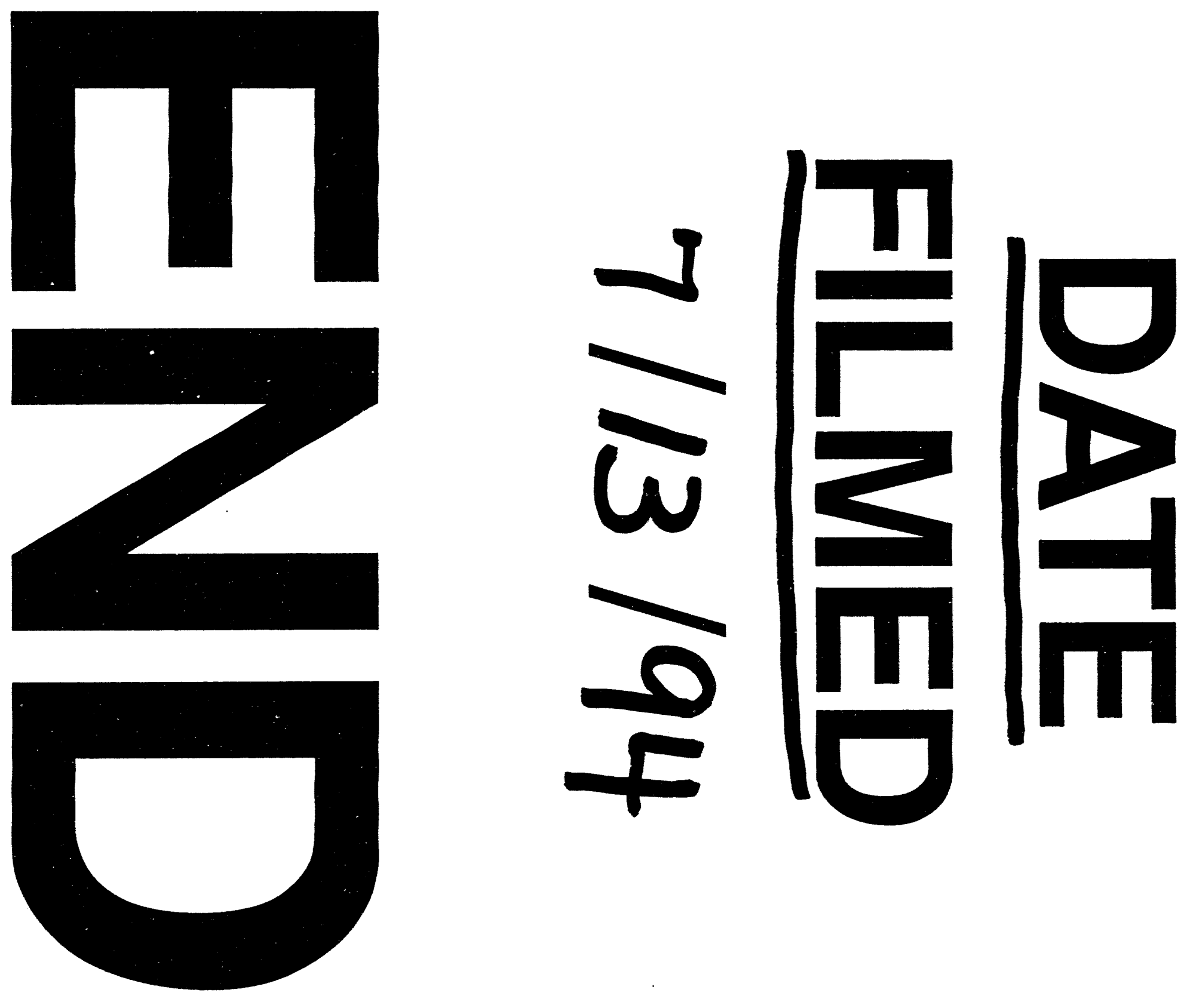
